\title{
Long-term soil accumulation of potentially toxic elements and selected organic pollutants through application of recycled phosphorus fertilizers for organic farming conditions
}

\author{
Lina Weissengruber $\cdot$ Kurt Möller $\cdot$ Markus Puschenreiter $\cdot$ Jürgen K. Friedel
}

Received: 22 March 2017 / Accepted: 14 January 2018/Published online: 25 January 2018

(C) The Author(s) 2018. This article is an open access publication

\begin{abstract}
The pollutant input and the risk of contamination by long-term application of recycled $\mathrm{P}$ fertilizers (RPFs) in European agricultural soils were estimated by a mass balance approach. Calculations based on literature data were carried out for the potentially toxic elements (PTEs) $\mathrm{Cd}, \mathrm{Cr}, \mathrm{Cu}, \mathrm{Ni}, \mathrm{Pb}$, $\mathrm{Zn}$ and for the persistent organic pollutants (POPs) PCBs, PAHs and polychlorinated dibenzo-dioxins and -furans. The PTE accumulation estimation during 200 years of fertilizer application, equivalent to $11 \mathrm{~kg} \mathrm{P} \mathrm{ha}^{-1}$ year $^{-1}$, the mean $\mathrm{P}$ export via harvested products on European stockless organic farms,
\end{abstract}

L. Weissengruber · J. K. Friedel ( $₫)$

Department of Sustainable Agricultural Systems,

University of Natural Resources and Life Sciences

Vienna, Gregor Mendel Straße 33, 1180 Vienna, Austria

e-mail: juergen.friedel@boku.ac.at

\section{K. Möller}

Institute of Crop Science, Fertilization and Soil Matter Dynamics, University of Hohenheim, Fruwirthstraße 20, 70593 Stuttgart, Germany

\section{Present Address:}

K. Möller

Center for Agricultural Technology Augustenberg, Institute of Applied Crop Science, Kutschenweg 20, 76287 Rheinstetten-Forchheim, Germany

\section{Puschenreiter}

Department of Forest and Soil Sciences, University of Natural Resources and Life Sciences Vienna, Peter-

Jordan-Straße 82, 1190 Vienna, Austria regarded soil background concentrations and proposed threshold concentrations. For PTEs, inputs were fertilizer application, atmospheric deposition and liming, output processes were leaching and crop harvest. The effect of varying site conditions was assessed by considering two precipitation excess (F) values and two soil $\mathrm{pH}$ values. For POPs, fertilizer application and the half-life time were considered. The PTE accumulation risk was low for most RPFs. For the analysed POPs no accumulation was found. The highest accumulation was found for all PTEs at $\mathrm{pH} 7$ and $\mathrm{F}=0.1 \mathrm{~m} \mathrm{year}^{-1}$, the lowest at $\mathrm{pH} 5$ and $\mathrm{F}=0.3 \mathrm{~m}$ year $^{-1}$. A high $\mathrm{P}$ concentration in fertilizers resulted in a low PTE flow per unit of P. Composts had the highest PTE accumulation risk due to lowest $P$ contents. Struvite, meat and bone meal, digestate of catering waste, ash and biosolids would be better suited as P fertilizers. The use of fertilizers should be regulated based on their pollutant-to-nutrient ratio.

Keywords Risk assessment - Heavy metals · Persistent organic pollutants - Phosphorus recycling · Pollutant-to-nutrient ratio $\cdot$ Cadmium

\section{Introduction}

Phosphorus (P) is an essential element for all living organisms and food production, but it is not treated sustainably in Europe. Through fertilization it ends up 
in surface water bodies or it is irretrievably lost by coincineration in municipal solid waste incinerators, power plants or cement kilns (Egle et al. 2015, 2016). At the current rate of extraction, phosphate rock reserves could peak in 2033 (Cordell and White 2011) and will be exhausted in the next few centuries (Elser 2012; Desmidt et al. 2014). This demonstrates that the reliance on non-renewable $\mathrm{P}$ sources for production of $P$ fertilizers directly contradicts both the principles of sustainable development and the principle of care in organic farming (IFOAM 2017). Furthermore, phosphate rock sources are increasingly polluted with cadmium $(\mathrm{Cd})$, thallium and the radioactive elements uranium and thorium (Egle et al. 2016). Therefore, we need a more efficient and sustainable $\mathrm{P}$ recycling within our societies.

The $\mathrm{P}$ status of long-term organically managed farms is currently becoming an issue of increasing concern (Nesme et al. 2012; Kolbe 2015). Phosphorus balances for organically managed arable cropping systems indicate that often more $\mathrm{P}$ is removed with the products than recycled via external inputs (Watson et al. 2002; Berry et al. 2003; Kolbe 2015; Ohm et al. 2017), leading to decreasing soil status in plant available soil P (Løes and Ogaard 1997; Kolbe 2015) which threatens the long-term sustainability of organic farming systems. Moreover, P shortage may also limit other processes such as symbiotic $\mathrm{N}_{2}$ fixation (Römer and Lehne 2004; Oberson et al. 2013) that have a direct impact on the farm nitrogen cycle and on yields. Therefore, outbalancing $\mathrm{P}$ removals via exported products and appropriate $\mathrm{P}$ fertilization is a major challenge in the organic farming sector for preservation of the long-term soil fertility. According to the principles of organic farming, non-renewable inputs should be reduced by reuse, recycling and efficient management of materials and energy in order to maintain and improve environmental quality, therefore, organic farming should decrease dependency on phosphate rock.

The most important potential recycling sources of $P$ in our societies are (Ott and Rechtberger 2012; Zoboli et al. 2016):

- Wastewater based residues.

- Slaughterhouse wastes (e.g. meat and bone meal).

- Urban organic waste.
These $\mathrm{P}$ sources, provided an efficient recycling, might replace approximately $50-70 \%$ of the current $P$ import from phosphate rock in European societies (Klinglmair et al. 2015; Zoboli et al. 2016). Koppelaar and Weikard (2013) analyzed the global P flow and found a substantial scope for $\mathrm{P}$ use reduction by $32 \%$ of phosphate rock supply in 2009, and $28 \%$ technologically recyclable $\mathrm{P}$ from waterways and wastewaters, but at high costs. However, any recycling may be hazardous due to the risk of the transfer of potentially toxic elements (PTEs), pathogens and contaminants, which may harm the product quality, the long-term soil fertility and the environment. These concerns for example have led to a ban of sewage sludge based recycled $\mathrm{P}$ fertilizers (RPFs) in organic farming in the seventies of last century. There is a huge body of publications addressing the potential consequences of nutrient recycling on soil contamination. Most of the publications address biosolids obtained after stabilization and hygienization of wastewaters (Sekhar et al. 2002; Herter et al. 2003; Udom et al. 2004; Dai et al. 2006; Eljarrat et al. 2008; Nogueira et al. 2009; Wu et al. 2012; Tavazzi et al. 2012), the most relevant potential P source. The loads of PTEs and organic contaminants of composts and digestates obtained from organic household wastes were also an issue of discussion (e.g. Amlinger et al. 2004; Berset and Holzer 1995; Brändli et al. 2007a, b; LfU 2007; Smith 2009a; Govasmark et al. 2011; Mairitsch et al. 2011). The two main groups of concern are PTEs and persistent organic pollutants (POPs). Potentially toxic elements may accumulate in the soil and lead to phytotoxic effects reducing the productivity of the soil, or they are taken up by the crops compromising the food quality and animal as well human health (Puschenreiter and Horak 2000; Kabata-Pendias 2011; de Vries et al. 2013). Persistent organic pollutants are substances that persist in the environment and pose a risk of causing adverse effects to human health and the environment. This group of priority pollutants consists of pesticides, industrial chemicals (such as polychlorinated biphenyls, PCBs) and unintentional by-products of industrial processes (such as dioxins and furans) (EU 2016). Polychlorinated biphenyls are a group of 209 congeners that were used in transformers, sealing compounds, isolators, coolants, flame retardants, plasticisers and other applications (Leschber 2006). Polychlorinated dibenzo- $p$-dioxins (PCDDs) include 75 congeners, polychlorinated dibenzo-furans 
(PCDFs) 135 congeners, together they are addressed as polychlorinated dibenzo-dioxins and -furans (PCDD/Fs) (Leschber 2006). They are emitted from metal industry, chemical industry, waste combustion plants and illegal waste combustion, in which the purification of waste gases was a big contributor to the reduction of pollution (Herter et al. 2003; Leschber 2006). Polycyclic aromatic hydrocarbons (PAHs) include several hundred congeners and have a wide diversity of physical, chemical and toxicological characteristics. They are found as by-products of incomplete combustion (Leschber 2006; Lerda 2011).

Currently, $80-90 \%$ of societal recoverable $\mathrm{P}$ sources are not permitted in organic farming due to public or private legislation standards (Løes et al. 2017). The average net $P$ export of the organic sector accounted for approximately 6-7 kg P ha ${ }^{-1}$ year $^{-1}$ (Kolbe 2015; Cooper et al. 2017). The remaining $10-20 \%$ of the societal recoverable P sources, currently permitted in organic farming, will not meet the $\mathrm{P}$ needs of the entire organic sector, even assuming that they are exclusively used on organically managed fields. This situation asks for a re-design of the $\mathrm{P}$ recycling and $\mathrm{P}$ fertilization approach within the organic community. The challenge is to increase the P recycling efficiency without compromising the longterm sustainability by accumulation of harmful substances. A holistic approach should consider the options and consequences of recycling of the major potential societal $\mathrm{P}$ sources. Furthermore, it should compare the effects of different potential $\mathrm{P}$ recycling sources on long-term soil fertility and soil contamination. A re-consideration of the appropriate $\mathrm{P}$ recycling for organic farming should also consider the products obtained from more advanced treatment technologies of societal organic wastes. For example, in the last two decades several new approaches were developed to treat urban organic household wastes (e.g. by anaerobic digestion instead of composting) or urban wastewaters. The two current main approaches of urban wastewaters treatment are (Herzel et al. 2015b; Egle et al. 2016; Kraus et al. 2017):

- Chemical approaches resulting in the production of struvite (magnesium ammonium phosphate) or different forms of water- and non water-soluble calcium phosphates.

- Thermal approaches aiming to recover P as ashes (with or without PTE depollution), chars, P-rich converter slags $\left(\mathrm{CaSiPO}_{4}\right)$ or calcined phosphates like ashes $\left(\mathrm{CaNaPO}_{4}\right)$ among others.

Some methods represent a combination of thermal and chemical approaches (e.g. Leachphos ${ }^{\circledR}$, where ashes are solubilized with acids). The aim of these treatments is to reduce the load of contaminants, either by selective $\mathrm{P}$ removal (chemical $\mathrm{P}$ recovery approaches), or by decontamination of organic contaminants due to the incineration process itself (thermal $\mathrm{P}$ recovery approaches). Several methods also reduce the specific PTE loads, e.g. by selective $\mathrm{P}$ precipitation, or by volatilization as chlorines at higher incineration temperatures (Kraus and Seis 2015).

The objective of this study was to assess the input and to estimate the long-term accumulation risk in European agricultural soils of PTEs and selected POPs related to the annual application of different societal $\mathrm{P}$ recycling sources and to assess how decontamination by thermal, chemical or chemico-physical approaches influences the soil accumulation risk of the addressed pollutants, in order to test following hypotheses:

1. The PTE and POP concentrations in fertilizers are the main factor for their accumulation in soil.

2. The source material and the production process of RPFs determine their contamination and the risk of PTE and POP accumulation in soil.

3. The regular use of recycled phosphorus fertilizers causes higher soil pollution risks (PTEs and POPs) than that of commonly used fertilizers.

4. The soil and climatic conditions have a minor relevance on the soil accumulation risk of PTEs.

\section{Materials and methods}

\section{Recycled P fertilizers}

The assessed RPFs derived from municipal organic waste, urban wastewater and meat production were compared to composts, cattle manure from conventional agriculture, phosphate rock and triple superphosphate as references. Information regarding the raw material of fertilizers and the manufacturing process is provided in Table 1. Central European average values for $\mathrm{P}$ and PTEs in all fertilizers are summarized in Table 2. The available fertilizers were 
Table 1 Raw material and manufacturing process of fertilizers

\begin{tabular}{|c|c|c|}
\hline Fertilizers & Main raw material & Treatment \\
\hline Organic household waste digestate OF & Organic household waste & Anaerobic digestion \\
\hline Catering waste digestate & Catering waste & Anaerobic digestion \\
\hline Biosolid dewatered & Sewage sludge & Hygienization, stabilization, dewatering \\
\hline Meat and bone meal $\mathrm{OF}$ & Slaughterhouse waste & Sterilization, drying, grinding \\
\hline Struvite Stuttgart & Urban wastewater & Sludge leaching \\
\hline Struvite Airprex ${ }^{\circledR}$ & Urban wastewater & Sludge precipitation \\
\hline Biosolid ash untreated & Sewage sludge & Incineration \\
\hline Biosolid ash Leachphos ${ }^{\circledR}$ & Sewage sludge ash & Ash solubilization with acids \\
\hline Calcined ash AshDec ${ }^{\circledR}$ & Sewage sludge ash & Calcination with $\mathrm{Na}$ or $\mathrm{K}$ \\
\hline Mephrec converter slag & Sewage sludge/ash & Metallurgical treatment \\
\hline \multicolumn{3}{|l|}{ Reference fertilizers } \\
\hline Green waste compost $\mathrm{OF}^{\mathrm{a}}$ & Plant residues of gardens & Composting \\
\hline Organic household waste compost OF & Organic household waste & Composting \\
\hline Catering waste compost & Food waste & Composting \\
\hline Cattle solid manure OF & Manure & - \\
\hline Phosphate rock OF & Phosphate rock & \\
\hline Triple superphosphate & Phosphate rock & Chemical, $\mathrm{Ca}\left(\mathrm{H}_{2} \mathrm{PO}_{4}\right)_{2}$ \\
\hline
\end{tabular}

${ }^{\text {a } O F}$ allowed in organic farming according to EU regulation EC 889/2008

Table 2 Mean concentration of potentially toxic elements and phosphorus in fertilizers on a dry weight base $\left(\mathrm{mg} \mathrm{kg}^{-1} \mathrm{DM}\right)$

\begin{tabular}{|c|c|c|c|c|c|c|c|c|}
\hline & $\mathrm{Cd}$ & $\mathrm{Cr}$ & $\mathrm{Ni}$ & $\mathrm{Pb}$ & $\mathrm{Cu}$ & $\mathrm{Zn}$ & $\mathrm{P}$ & References \\
\hline Organic household waste digestate OF & 0.4 & 19 & 13 & 20 & 49 & 200 & 6800 & 1 \\
\hline Catering waste digestate & 0.3 & 8 & 9 & 4 & 40 & 177 & 22,100 & 1 \\
\hline Biosolid dewatered & 1.0 & 37 & 29 & 37 & 327 & 937 & 35,700 & 3 \\
\hline Meat and bone meal OF & 0.2 & 14 & 3 & 3 & 11 & 109 & 53,100 & 1 \\
\hline Struvite Stuttgart & 0.4 & 14 & 5 & 6 & 19 & 260 & 169,630 & $1,4,5$ \\
\hline Struvite Airprex ${ }^{\circledR}$ & 0.3 & 16 & 16 & 60 & 42 & 86 & 91,686 & $1,6,7$ \\
\hline Biosolid ash untreated & 2.8 & 96 & 37 & 129 & 875 & 2479 & 70,900 & 7,5 \\
\hline Biosolid ash Leachphos ${ }^{\circledR}$ & 2.6 & 34 & 14 & 25 & 851 & 1390 & 131,000 & 5,8 \\
\hline Calcined ash AshDec ${ }^{\circledR}$ & 0.3 & 127 & 56 & 57 & 441 & 1710 & 77,000 & 5,8 \\
\hline Mephrec converter slags & 0.3 & 89 & 14 & 13 & 107 & 69 & 51,976 & $8,9,10$ \\
\hline Green waste compost OF & 0.4 & 23 & 14 & 32 & 34 & 154 & 2200 & 1 \\
\hline Organic household waste compost OF & 0.4 & 22 & 12 & 28 & 41 & 150 & 3100 & 1 \\
\hline Catering waste compost & 0.5 & 28 & 18 & 45 & 54 & 213 & 3600 & 1 \\
\hline Cattle solid manure OF & 0.8 & 28 & 19 & 9 & 32 & 107 & 6313 & 2 \\
\hline Phosphate rock OF & 19 & 152 & 28 & 12 & 17 & 221 & 124,431 & 11 \\
\hline Triple superphosphate & 62 & 229 & 21 & 15 & 15 & 354 & 198,653 & 12 \\
\hline
\end{tabular}

1 Möller and Schultheiß (2014), 2 AROMIS (2016), 3 Wollmann and Möller (2015), 4 Pinnekamp et al. (2011), 5 Steinmetz et al. (2014), 6 Kraus and Seis (2015), 7 Langeveld (2014), 8 Herzel et al. (2015a), 9 Scheidig (2009), 10 Scheidig et al. (2014), 11 Kratz and Schnug (2005), 12 Dittrich and Klose (2008). For abbreviations see Table 1 
considered on a high and a low POP contamination level (Table 3).

The following fertilizers are currently allowed for use in organic farming according to EU regulation EC (2008): Green waste composts, organic household waste compost, digestate, meat and bone meal, conventional animal manures and phosphate rock. These fertilizers are indicated in the following text with the additional specification "OF".

The calculations of pollutant inputs and accumulation risks were performed for a time span of 200 years of fertilizer application equivalent to $11 \mathrm{~kg} \mathrm{P} \mathrm{ha}^{-1}$ year $^{-1}\left(25.2 \mathrm{~kg} \mathrm{P}_{2} \mathrm{O}_{5} \mathrm{ha}^{-1}\right.$ year $\left.^{-1}\right)$, which is an average $\mathrm{P}$ export via crops on European organic arable stockless farms (Lindenthal 2000; Berry et al. 2003; Möller and Stinner 2010; Cooper et al. 2017).

Model description for the risk assessment of potentially toxic element accumulation in soils

The included PTE input routes to soil were atmospheric deposition, liming and fertilization. Input of PTEs and their accumulation potential were compared to the current soil pollution (soil background concentration) and to proposed soil threshold values.

This study included the elements regulated in the sludge directive (EU Directive 86/278/EEC 1986) except mercury, because it is volatile (Steinnes 2013a) and is not covered completely by the model. The assessment of the PTE accumulation risks in European agricultural top soils was based on a mass balance approach applied by Smolders (2013), Six and Smolders (2014) and the European Scientific
Committee on Toxicology, Ecotoxicology and the Environment, CSTEE (2002) for assessing the cadmium accumulation in European agricultural soils. The model considered the input of pollutants by fertilizer application, atmospheric deposition and liming and the output via leaching, plant uptake and crop removal.

$\Delta \mathrm{C}_{\text {soil }}=$ INPUT - OUTPUT

$\Delta \mathrm{C}_{\text {soil }}$ was the change in PTE concentrations in the plough layer $(25 \mathrm{~cm})$ in $\mathrm{g} \mathrm{ha}^{-1}$ year $^{-1}$. The concentration of PTEs in soil at year $\mathrm{i}\left(\mathrm{C}_{\text {soil i }}\right.$ in $\left.\mathrm{mg} \mathrm{kg}^{-1}\right)$ was calculated from the annual net PTE balance (input - output in $\mathrm{g}_{\text {PTEs }} \mathrm{ha}^{-1}$ ) in year ${ }_{\mathrm{i}-1}$ and soil PTE concentration in year ${ }_{i-1}$ as:

$\mathrm{C}_{\text {soil } \mathrm{i}}=\mathrm{C}_{\text {soil } \mathrm{i}-1}+\frac{\text { INPUT }- \text { OUTPUT }}{\mathrm{M}_{\text {soil }}}$

For $\mathrm{C}_{\mathrm{soil}} \mathrm{i}-1=\mathrm{PTE}$ concentration in soil in the previous year $\left(\mathrm{mg} \mathrm{kg}^{-1}\right)$, Input $=$ the annual sum of PTEs in fertilizer, atmospheric deposition and lime $\left(\mathrm{g} \mathrm{ha}^{-1}\right)$, Output $=$ the annual sum of PTEs in leaching losses and harvested crop parts $\left(\mathrm{g} \mathrm{ha}^{-1}\right), \mathrm{M}_{\text {soil }}=$ soil mass in the plough layer $\left(\mathrm{Mg} \mathrm{ha}^{-1}\right)$, The calculation refers to the soil mass $\mathrm{M}_{\text {soil }}$ in the plough layer with a bulk density of $1.3 \mathrm{~kg} \mathrm{dm}^{3}$ and a depth of $25 \mathrm{~cm}$, which are $3250 \mathrm{Mg} \mathrm{ha}^{-1}$. The PTE content in harvested crop parts in year $\mathrm{i}$ (Crop export ${ }_{\mathrm{i}}$ ) was calculated as a function of PTE concentration in soil:

Crop export $_{\mathrm{i}}=\mathrm{TF} * \mathrm{C}_{\text {soil }-1} *$ crop yield

Table 3 Organic pollutant and phosphorus concentration in fertilizer dry weight for two contamination levels

\begin{tabular}{|c|c|c|c|c|c|c|c|}
\hline \multirow[t]{2}{*}{ Contamination level } & \multicolumn{2}{|c|}{ PCB $\left(\mathrm{mg} \mathrm{kg}^{-1}\right)$} & \multicolumn{2}{|c|}{ PAH $\left(\mathrm{mg} \mathrm{kg}^{-1}\right)$} & \multicolumn{2}{|c|}{ PCDD/F (ng TEQ kg ${ }^{-1}$ ) } & \multirow[t]{2}{*}{ References } \\
\hline & Low & High & Low & High & Low & High & \\
\hline Green waste compost OF & 0.01 & 0.04 & 0.38 & 6.40 & 0.003 & 0.005 & $4,1,8$ \\
\hline Organic household waste compost OF & 0.01 & 0.09 & 0.38 & 22.0 & 0.004 & 0.005 & $4,1,8$ \\
\hline Biosolid & 0.02 & 0.18 & 18.0 & 46.0 & 0.018 & 0.180 & $6,3,11$ \\
\hline Organic household waste digestate OF & 0.02 & 0.03 & 0.12 & 1.60 & 0.003 & 0.015 & $7,1,8$ \\
\hline Meat and bone meal & n.a. & n.a. & n.a. & n.a. & 0.0001 & 0.001 & 1,12 \\
\hline Solid farmyard manure & 0.01 & 0.04 & 0.01 & 0.14 & 0.004 & 0.020 & $5,2,9,10,11$ \\
\hline
\end{tabular}

For abbreviations: see Tables 1 and 4. n.a. not available; 1 Möller and Schultheiß (2014); 2 AROMIS (2016); 3 Wollmann and Möller (2015); 4 Brändli et al. 2007a; 5 Herter et al. (2003); 6 Gawlik and Bidoglio (2006); 7 Lindenblatt et al. (2007); 8 Beníšek et al. (2015); 9 Rey-Salgueiro et al. (2008); 10 Hough et al. (2012); 11 Stevens and Jones (2003); 12 FAO (2004) 
Table 4 Transfer factors (TF) of wheat grain and the partitioning coefficients (KD) used in the model

\begin{tabular}{|c|c|c|c|}
\hline & $\mathrm{TF}$ & \multicolumn{2}{|c|}{ References TF } \\
\hline $\mathrm{Cd}$ & 0.15 & \multicolumn{2}{|c|}{ Puschenreiter and Horak (2000) } \\
\hline $\mathrm{Cr}$ & 0.04 & \multicolumn{2}{|c|}{ Lavado et al. (2007) } \\
\hline $\mathrm{Cu}$ & 0.30 & \multicolumn{2}{|c|}{ Puschenreiter and Horak (2000) } \\
\hline $\mathrm{Ni}$ & 0.07 & \multicolumn{2}{|c|}{ Lavado et al. (2007) } \\
\hline $\mathrm{Pb}$ & 0.08 & \multicolumn{2}{|c|}{ Lavado et al. (2007) } \\
\hline $\mathrm{Zn}$ & 0.36 & \multicolumn{2}{|c|}{ Puschenreiter and Horak (2000) } \\
\hline & $\begin{array}{l}\text { KD in soil } \\
\text { pH } 5\end{array}$ & $\begin{array}{l}\text { KD in soil } \\
\text { pH } 7\end{array}$ & References KD \\
\hline $\mathrm{Cd}$ & 59 & 818 & $\begin{array}{l}\text { EPA (1999, Appendix } \\
\text { C) }\end{array}$ \\
\hline $\mathrm{Cr}(\mathrm{III})$ & 1048 & 28,649 & $\begin{array}{l}\text { Hassan and Garrison } \\
\text { (1996) }\end{array}$ \\
\hline $\mathrm{Cu}$ & 900 & 2000 & Sauvé et al. (2000) \\
\hline $\mathrm{Ni}$ & 90 & 2400 & Sauvé et al. (2000) \\
\hline $\mathrm{Pb}$ & 5532 & 21,750 & $\begin{array}{l}\text { EPA (1999, Appendix } \\
\text { F) }\end{array}$ \\
\hline $\mathrm{Zn}$ & 150 & 3000 & Sauvé et al. (2000) \\
\hline
\end{tabular}

Units: TF is total PTE concentration in plant divided by the total concentration in soil $\left(\mathrm{mg} \mathrm{kg}^{-1}\right) ; \mathrm{KD}$ is in $\left(\mathrm{L} \mathrm{kg}^{-1}\right)$

Crop export $_{\mathrm{i}}=$ annual PTE uptake into wheat grain in year $\mathrm{i}\left(\mathrm{g} \mathrm{ha}^{-1}\right), \mathrm{TF}=$ transfer factor for wheat grain, Crop yield $=$ average annual yield of wheat grain $3 \mathrm{Mg} \mathrm{ha}^{-1}$.

In order to assess the PTE removal via exported products, the transfer factor for wheat grain (Puschenreiter and Horak 2000; Lavado et al. 2007) and a continuous cropping of wheat with an average annual yield of $3 \mathrm{Mg} \mathrm{ha}^{-1}$ was assumed. This is a low average wheat yield in organic production (Beckmann et al. 2001) taking into account that ley cropping without nutrient removal are typically part of the crop rotation on organic farms. The average annual yield of $3 \mathrm{Mg} \mathrm{ha}^{-1}$ equals a $\mathrm{P}$ export from the field of $11 \mathrm{~kg} \mathrm{P} \mathrm{ha}^{-1}$ year $^{-1}$ (Stein-Bachinger et al. 2004) and also corresponds to the above-mentioned mean $\mathrm{P}$ export in harvested crop parts in stockless organic farms. The transfer factor (TF) is the PTE concentration of an element in the crop divided by the PTE concentration in the soil. The TF values are shown in Table 4. Transfer factors for wheat grain were used because it is an important commodity and carbohydrate source in Europe.
Leaching is the outflow of PTEs dissolved in soil pore water from the topsoil. It is a function of water percolation through the soil-expressed as precipitation excess $\mathrm{F}$ in $\mathrm{m}$ year ${ }^{-1}$ —and the PTE concentration in pore water. To predict the PTE concentration in pore water, a distribution coefficient (KD in $\mathrm{L} \mathrm{kg}^{-1}$ ) was used. $\mathrm{KD}$ is a measure for the relative partitioning of an element between the solid phase $\left(\mathrm{C}_{\text {soil }}\right)$ and the solution phase $\left(\mathrm{C}_{\text {solution }}\right)$ :

$$
\begin{aligned}
\text { Leaching }\left(\mathrm{g} \mathrm{ha}^{-1} \text { year }^{-1}\right)= & \mathrm{C}_{\text {soil } \mathrm{i}-1} / \mathrm{KD} \\
& * \text { precipitation excess } \mathrm{F} \\
& * 10,000
\end{aligned}
$$

$\mathrm{C}_{\text {soil }} \mathrm{i}-1=$ Compound concentration in soil $\left(\mathrm{mg} \mathrm{kg}^{-1}\right), \mathrm{KD}=$ distribution coefficient $\left(\left(\mathrm{mg} \mathrm{kg}^{-1}\right) /\right.$ $\left.\left(\mathrm{mg} \mathrm{L}^{-1}\right)=\mathrm{L} \mathrm{kg}^{-1}=\mathrm{dm}^{3} \mathrm{~kg}^{-1}\right), \mathrm{F}=$ precipitation excess $\left(\mathrm{m}\right.$ year $\left.{ }^{-1}\right)$, Leaching $\left(\mathrm{mg} \mathrm{kg}^{-1} /\left(\mathrm{dm}^{3} \mathrm{~kg}^{-1}\right) *\right.$ $\mathrm{m} \mathrm{year}^{-1} * 10,000=\mathrm{mg} \mathrm{m}^{-2}$ year $^{-1} * 10=\mathrm{g} \mathrm{ha}^{-1}$ year $^{-1}$ ).

The KD is the PTE concentration in the solid phase divided by the PTE concentration in the solution phase (Table 4). It varies widely according to $\mathrm{pH}$, clay content, organic carbon, iron content, PTE concentration in soil and-if predicted and not measured-on the empirical regression model. Among these factors, the $\mathrm{pH}$ value had the largest effect (Young 2013; Kabata-Pendias 2011). Therefore, the mean KD values from literature for $\mathrm{pH} 5$ and for $\mathrm{pH} 7$ were used in this calculation (EPA 1999; Sauvé et al. 2000; Hassan and Garrison 1996). To calculate the water percolation in the soil, a high rainfall scenario $\left(F=0.3 \mathrm{~m}\right.$ year $\left.^{-1}\right)$ and a low rainfall scenario $\left(\mathrm{F}=0.1 \mathrm{~m} \mathrm{year}^{-1}\right)$ were calculated. The European average precipitation excess is $0.2 \mathrm{~m} \mathrm{year}^{-1}$, in Mediterranean region it can be reduced to $0.05 \mathrm{~m} \mathrm{year}^{-1}$ and for regions with high rainfall a precipitation excess of $0.3 \mathrm{~m} \mathrm{year}^{-1}$ is possible (Smolders 2013; Six and Smolders 2014).

The calculations were based on the soil background concentrations of PTEs already present in the soil. These values for European soils were taken from an European survey (Salminen et al. 2005). The PTE threshold values were taken from a recommendation paper by the Joint Research Centre, the European Commission" in-house science service (Gawlik and Bidoglio 2006) because no legal European thresholds exist (Table 5). 
Table 5 Input of potential toxic elements to soil via atmospheric deposition, lime and fertilizers (referring to $11 \mathrm{~kg} \mathrm{P} \mathrm{ha}^{-1}$ year $^{-1}$ ) after 200 years compared to soil background concentration and threshold values

Soil background concentrations and proposed threshold values (aqua regia basis) were converted from $\mathrm{mg} \mathrm{kg}^{-1}$ to $\mathrm{kg} \mathrm{ha}{ }^{-1}$ assuming a soil bulk density in the plough horizon $(25 \mathrm{~cm})$ of $1.3 \mathrm{~g} \mathrm{~cm}^{-3}$. 1 Salminen et al. (2005); 2 Gawlik and Bidoglio (2006), 3 Smolders (2013), 4 Eriksen et al. (2009). For abbreviations and fertilizer references see Tables 1 and 2

\begin{tabular}{llllllll}
\hline PTE input to soil $\left(\mathrm{kg} \mathrm{ha}^{-1}\right)$ & $\mathrm{Cd}$ & $\mathrm{Cr}$ & $\mathrm{Cu}$ & $\mathrm{Ni}$ & $\mathrm{Pb}$ & $\mathrm{Zn}$ & References \\
\hline Soil background concentration & 0.92 & 106 & 53.3 & 100 & 78 & 198 & 1 \\
Proposed threshold values & 3.25 & 244 & 163 & 163 & 228 & 488 & 2 \\
Input via atmospheric deposition & 0.07 & 1.85 & 6.77 & 1.99 & 2.38 & 45.2 & 3,4 \\
Input via lime & 0.03 & 0.18 & 0.27 & 0.15 & 0.19 & 0.40 & 2 \\
Input via fertilizers & & & & & & & \\
Organic household waste digestate OF & 0.13 & 6.08 & 15.8 & 4.06 & 6.47 & 64.4 & \\
Catering waste digestate & 0.03 & 0.75 & 3.96 & 0.94 & 0.38 & 17.5 & \\
Biosolid dewatered & 0.06 & 2.25 & 20.1 & 1.80 & 2.25 & 57.5 & \\
Meat and bone meal OF & 0.01 & 0.56 & 0.47 & 0.14 & 0.12 & 4.49 & \\
Struvite Stuttgart & 0.01 & 0.18 & 0.25 & 0.06 & 0.08 & 3.36 & \\
Struvite Airprex ${ }^{\circledR}$ & 0.01 & 0.39 & 1.01 & 0.38 & 1.44 & 2.05 & \\
Biosolid ash untreated & 0.09 & 2.95 & 27.0 & 1.16 & 3.98 & 76.5 & \\
Biosolid ash Leachphos ${ }^{\circledR}$ & 0.04 & 0.57 & 14.2 & 0.23 & 0.42 & 23.2 & \\
Calcined ash AshDec ${ }^{\circledR}$ & 0.01 & 3.61 & 12.5 & 1.60 & 1.61 & 48.6 & \\
Mephrec converter slag & 0.01 & 3.75 & 4.50 & 0.57 & 0.53 & 2.91 & \\
Green waste compost OF & 0.40 & 22.7 & 34.2 & 13.7 & 32.2 & 153 & \\
Organic household compost OF & 0.25 & 15.2 & 28.6 & 8.61 & 19.7 & 106 & \\
Catering waste compost & 0.28 & 17.1 & 33.0 & 10.6 & 27.2 & 130 & \\
Cattle solid manure OF & 0.28 & 9.57 & 11.1 & 6.65 & 3.15 & 37.1 & \\
Phosphate rock OF & 0.34 & 2.68 & 0.30 & 0.50 & 0.21 & 3.89 & \\
Triple superphosphate & 0.68 & 2.52 & 0.17 & 0.23 & 0.16 & 3.90 & \\
\hline & & & & & & & \\
& & & & & & &
\end{tabular}

Model description for accumulation of persistent organic pollutants in soil

The three groups $\mathrm{PAH}, \mathrm{PCB}$ and $\mathrm{PCDD} / \mathrm{F}$ were considered as an example for POPs, because they are still important pollutants in soil and the database for calculations is available. A mass balance model according to Amlinger et al. (2004) was used to assess the accumulation of persistent organic pollutants in soil. Accumulation problems of organics arise, if the persistence of compounds in soil is high (EU 2016). The accumulation was computed with the following iterative formula:

$$
\begin{aligned}
\mathrm{C}_{\text {soil }}\left(\mathrm{mg} \mathrm{kg}^{-1}\right)= & \mathrm{C}_{0} * \mathrm{X}^{\mathrm{n}}+\left((\mathrm{If}+\mathrm{Id}) / \mathrm{M}_{\text {soil }}\right) \\
& *\left(\left(1-\mathrm{X}^{\mathrm{n}}\right) /(1-\mathrm{X})\right)
\end{aligned}
$$

(Amlinger et al. 2004)

$\mathrm{C}_{0}=$ Soil background concentration $\mathrm{mg} \mathrm{kg}^{-1}$, $\mathrm{X}=\mathrm{e}^{-\ln 2 /(\mathrm{T} 1 / 2)}, \mathrm{T}^{1 / 2}=$ Half-life time of compound in soil in years, $\mathrm{n}=$ year of which accumulation is considered, If $=$ Compound input with fertilizer $\left(\mathrm{g} \mathrm{ha}^{-1}\right.$ year $\left.^{-1}\right), \quad \mathrm{Id}=$ Compound input with atmospheric deposition $\left(\mathrm{g} \mathrm{ha}^{-1}\right.$ year $\left.^{-1}\right), \mathrm{M}_{\text {soil }}=$ Soil mass plough horizon $\left(\mathrm{Mg} \mathrm{ha}^{-1}\right)$.

The most critical parameter was the assumed halflife time which is usually determined in lab experiments (OECD 2005), and the bibliographical references vary widely (Table 6). In the calculation, mean values of literature data were used. Also the range of $\mathrm{PCB}, \mathrm{PAH}$ and PCDD/F content in fertilizers was broad, therefore scenarios with fertilizers of low and high contamination level were calculated as shown in Table 3. Soil guidance values (according to the Austrian threshold values ÖNORM S2088-2 2004) and soil background concentrations for organic pollutants are shown in Table 6. Leaching and plant uptake of POPs were not considered. The assessed POPs-as apolar molecules - are highly bound to the organic matter, reducing their availability to plant roots (Smith 2009b) and leaching into groundwater is unlikely (Leschber 2006; Gawlik and Bidoglio 2006; Clarke and Cummins 2015; Tavazzi et al. 2012). 
Table 6 Persistent organic pollutant input to soil in 200 years via fertilizers (referring to $11 \mathrm{~kg} \mathrm{P} \mathrm{ha}^{-1}$ year $^{-1}$ ) and atmospheric deposition, compared to half-life time, soil background concentration and guidance values

\begin{tabular}{|c|c|c|c|}
\hline & Unit & & References \\
\hline \multicolumn{4}{|l|}{$P C B$} \\
\hline Digestate & $\mathrm{kg} \mathrm{ha}^{-1}$ & 0.003 & For fertilizer references see Table 3 \\
\hline Sewage sludge & $\mathrm{kg} \mathrm{ha}^{-1}$ & 0.011 & \\
\hline Farmyard manure & $\mathrm{kg} \mathrm{ha}^{-1}$ & 0.015 & \\
\hline Green waste compost & $\mathrm{kg} \mathrm{ha}^{-1}$ & 0.043 & \\
\hline Organic waste compost & $\mathrm{kg} \mathrm{ha}^{-1}$ & 0.054 & \\
\hline Atmospheric deposition & $\mathrm{kg} \mathrm{ha}^{-1}$ & 0.070 & $\begin{array}{l}\text { Suominen et al. (2014), Amlinger et al. (2004), Brändli et al. (2007b) and } \\
\text { Arellano et al. } 2015\end{array}$ \\
\hline \multirow[t]{3}{*}{ Half-life time in soil } & years (mean) & 14 & Leschber (2006), Amlinger et al. (2004), Creaser et al. 2007 and \\
\hline & years (max.) & 31 & Bruckmann et al. (2013) \\
\hline & years (min.) & 1 & \\
\hline $\begin{array}{l}\text { Initial soil background } \\
\text { concentration }\end{array}$ & $\mathrm{kg} \mathrm{ha}^{-1}$ & 0.045 & Amlinger et al. (2004) and Creaser et al. (2007) \\
\hline Soil guidance value & $\mathrm{kg} \mathrm{ha}^{-1}$ & 0.975 & ÖNORM S 2088-2 (2004) \\
\hline Digestate & $\mathrm{kg} \mathrm{ha}^{-1}$ & 0.16 & For fertilizer references see Table 3 \\
\hline Sewage sludge & $\mathrm{kg} \mathrm{ha}^{-1}$ & 2.83 & \\
\hline Farmyard manure & $\mathrm{kg} \mathrm{ha}^{-1}$ & 0.05 & \\
\hline Green waste compost & $\mathrm{kg} \mathrm{ha}^{-1}$ & 6.40 & \\
\hline Organic waste compost & $\mathrm{kg} \mathrm{ha}^{-1}$ & 13.4 & \\
\hline Atmospheric deposition & $\mathrm{kg} \mathrm{ha}^{-1}$ & 0.53 & Amlinger et al. (2004), Suominen et al. (2014) and Brändli et al. (2007b) \\
\hline \multirow[t]{3}{*}{ Half-life time in soil } & years (mean) & 12 & $\begin{array}{l}\text { Leschber (2006), Amlinger et al. (2004), Creaser et al. (2007) and } \\
\text { Bruckmann et al. (2013) }\end{array}$ \\
\hline & years (max.) & 32 & \\
\hline & years (min.) & 5 & \\
\hline $\begin{array}{l}\text { Initial soil background } \\
\text { concentration }\end{array}$ & $\mathrm{kg} \mathrm{ha}^{-1}$ & 1.38 & Amlinger et al. (2004) and Brändli et al. (2007b) \\
\hline Soil guidance value & $\mathrm{kg} \mathrm{ha}^{-1}$ & 3.25 & ÖNORM S 2088-2 (2004) \\
\hline \multicolumn{4}{|l|}{$P C D D / F$} \\
\hline Digestate & mg TEQ ha ${ }^{-1}$ & 1.49 & For fertilizer references see Table 3 \\
\hline Sewage sludge & mg TEQ ha ${ }^{-1}$ & 11.1 & \\
\hline Farmyard manure & mg TEQ ha ${ }^{-1}$ & 6.97 & \\
\hline Meat and bone meal & mg TEQ ha ${ }^{-1}$ & 0.02 & \\
\hline Green waste compost & mg TEQ ha ${ }^{-1}$ & 5.20 & \\
\hline Organic waste compost & mg TEQ ha ${ }^{-1}$ & 3.30 & \\
\hline Atmospheric deposition & mg TEQ ha ${ }^{-1}$ & 0.38 & Amlinger et al. (2004), Suominen et al. (2014) and Brändli et al. (2007b) \\
\hline \multirow[t]{3}{*}{ Half-life time in soil } & years (mean) & 30 & $\begin{array}{l}\text { Leschber (2006), Amlinger et al. (2004), Umlauf et al. (2010) and } \\
\text { Bruckmann et al. (2013) }\end{array}$ \\
\hline & years (max.) & 100 & \\
\hline & years (min.) & 5 & \\
\hline $\begin{array}{l}\text { Initial soil background } \\
\text { concentration }\end{array}$ & mg TEQ ha ${ }^{-1}$ & 18.6 & Amlinger et al. (2004) and Brändli et al. (2007b) \\
\hline Soil guidance value & mg TEQ ha ${ }^{-1}$ & 32,500 & ÖNORM S 2088-2 (2004) \\
\hline
\end{tabular}

Polychlorinated biphenyls (PCB), polycyclic aromatic hydrocarbons (PAH) and polychlorinated dibenzo-dioxins and -furans (PCDD/ F) 
System boundaries

Volatilization of PTEs was not considered by the model as well as other interactions which could influence the mobility of PTEs and the degradation of POPs, like fixation of PTEs through $\mathrm{P}$ added by fertilizers or site-specific differences. Also other risks like metal accumulation into soil organisms, leaching to groundwater, transport with surface water or wind, direct uptake of soil by humans and animals have not been considered here.

\section{Results}

Input routes of pollutants to soil

The assessment of the 200-years PTE inputs by fertilizers, liming and atmospheric deposition indicated that these inputs are expected to be small compared to the already existing PTE background concentrations in soil (Table 5). Between 28\% (Cd) and $61 \%(\mathrm{Ni})$ of the proposed thresholds were already filled with the existing soil background concentration. Also the assessed sum of all inputs over 200 years was little compared to soil background concentration and would not reach the proposed threshold values. Liming contributed less to the pollution then most fertilizers. The expected atmospheric deposition of pollutants was considerable, however, most fertilizers would have a higher input at least for some elements. With input rates below the atmospheric deposition, meat and bone meal, struvite, digestate of catering waste and treated ashes turned out to be the cleanest fertilizers in relation to their $P$ content. The variability among the fertilizers can be compared on the basis of the ratio of PTE input by fertilizers and atmospheric input (Fig. 1). PTEs in composts and cattle manure, and some elements in phosphate rock, triple superphosphate and untreated biosolid ash exceeded the atmospheric input by far. Fertilizers with a high PTEto-phosphorus ratio, like composts, showed the highest PTE input to soil.

POPs entered the agricultural soil via fertilization and atmospheric deposition more or less to the same extent. The fertilizer input and atmospheric deposition of POPs in 200 years was compared to the initial soil background concentration, guidance values and the half-life time (Table 6). Soil background concentration was low compared to the guidance values, it reached $5 \%$ for $\mathrm{PCB}, 43 \%$ for $\mathrm{PAH}$ and $0.06 \%$ for PDCC/F. For PCB, atmospheric deposition was the main route compared to fertilizer input. Main PHA input was caused by organic waste compost, green waste compost and sewage sludge, digestate and farmyard manure were below the atmospheric deposition. For PCDD/F the soil guidance value was far higher than any input. Expected PCDD/F input via atmospheric deposition was considerably lower than via fertilizers, except for meat and bone meal. PCDD/ $\mathrm{F}$ contamination level by fertilizer application declined as following in descending order: sewage sludge, farmyard manure, green waste compost, organic waste compost and digestate (Table 6).

The PTE and POP inputs provided information about the pollution loads in fertilizers and input routes. Additional information was gained from calculating the soil accumulation risk with the mass balance models which included the PTE output by leaching and harvested crop parts and the POP decomposition in soil.

Accumulation risk of pollutants in soil estimated by the mass balance models

The model estimates for PTE accumulation risks after 200 years of fertilizer application (equivalent to $11 \mathrm{~kg} \mathrm{P} \mathrm{ha}^{-1}$ ) indicated that with none of the assessed fertilizers the proposed soil threshold values would be reached (Fig. 2). However, the results revealed strong differences in the accumulation risk for the individual PTEs. An overall low $\mathrm{Cd}$ accumulation risk in soil, in relation to the threshold values, was predicted for all RPFs except for triple superphosphate, a moderate accumulation risk for $\mathrm{Cu}, \mathrm{Cr}$ and $\mathrm{Pb}$, and the highest accumulation risk for $\mathrm{Ni}$ and $\mathrm{Zn}$ (Fig. 2; Table 8). Soil $\mathrm{pH}$ and precipitation excess, affecting the element output from the soil via leaching and harvested crop parts, is expected to have a stronger effect on $\mathrm{Cd}, \mathrm{Ni}$ and $\mathrm{Zn}$ accumulation than the type of fertilizer. For $\mathrm{Cr}$, $\mathrm{Cu}$ and $\mathrm{Pb}$, it was the opposite: the PTE amount in fertilizers had a stronger effect on their accumulation than the output losses, varying with soil $\mathrm{pH}$ and precipitation excess (Fig. 2).

For POPs, a mass balance model considering the soil background concentration, the contamination level of the fertilisers, the atmospheric deposition, and their half-life time was used. The mass balance 
Table 7 Total output $\left(\mathrm{kg} \mathrm{ha}^{-1}\right)$ of PTEs after 200 years of fertilization (equivalent to $11 \mathrm{~kg} \mathrm{P}^{-1}$ ) by leaching and in harvested crop parts

(a)

\begin{tabular}{|c|c|c|c|c|c|c|c|c|c|c|c|c|}
\hline & $\begin{array}{l}\mathrm{Cd} \\
\mathrm{pH} 5 \\
\mathrm{~F} 0.1\end{array}$ & $\begin{array}{l}\mathrm{Cd} \\
\mathrm{pH} 5 \\
\mathrm{~F} 0.3\end{array}$ & $\begin{array}{l}\text { Cd } \\
\text { pH } 7 \\
\text { F } 0.1\end{array}$ & $\begin{array}{l}\mathrm{Cd} \\
\mathrm{pH} 7 \\
\mathrm{~F} 0.3\end{array}$ & $\begin{array}{l}\mathrm{Cr} \\
\mathrm{pH} 5 \\
\mathrm{~F} 0.1\end{array}$ & $\begin{array}{l}\mathrm{Cr} \\
\mathrm{pH} 5 \\
\mathrm{~F} 0.3\end{array}$ & $\begin{array}{l}\mathrm{Cr} \\
\mathrm{pH} 7 \\
\mathrm{~F} 0.1\end{array}$ & $\begin{array}{l}\mathrm{Cr} \\
\mathrm{pH} 7 \\
\mathrm{~F} 0.3\end{array}$ & $\begin{array}{l}\mathrm{Cu} \\
\mathrm{pH} 5 \\
\mathrm{~F} 0.1\end{array}$ & $\begin{array}{l}\mathrm{Cu} \\
\mathrm{pH} 5 \\
\mathrm{~F} 0.3\end{array}$ & $\begin{array}{l}\mathrm{Cu} \\
\mathrm{pH} 7 \\
\mathrm{~F} 0.1\end{array}$ & $\begin{array}{l}\mathrm{Cu} \\
\mathrm{pH} 7 \\
\mathrm{~F} 0.3\end{array}$ \\
\hline No fertilizer & 0.64 & 0.95 & 0.09 & 0.22 & 7.03 & 18.03 & 1.03 & 1.03 & 6.34 & 13.34 & 4.34 & 7.34 \\
\hline Organic household waste digestate OF & 0.69 & 1.04 & 0.05 & 0.23 & 7.11 & 18.11 & 1.11 & 1.11 & 7.14 & 15.14 & 5.14 & 9.14 \\
\hline Catering waste digestate & 0.65 & 0.97 & 0.09 & 0.22 & 6.78 & 17.78 & 0.78 & 1.78 & 7.30 & 13.30 & 5.30 & 8.30 \\
\hline Biosolid dewatered & 0.66 & 0.99 & 0.10 & 0.22 & 7.28 & 18.28 & 1.28 & 1.28 & 7.44 & 15.44 & 5.44 & 9.44 \\
\hline Meat and bone meal OF & 0.65 & 0.96 & 0.09 & 0.22 & 6.59 & 17.59 & 0.59 & 1.59 & 6.81 & 12.81 & 4.81 & 7.81 \\
\hline Struvite Stuttgart & 0.65 & 0.96 & 0.10 & 0.22 & 7.21 & 18.21 & 1.21 & 1.21 & 6.59 & 12.59 & 4.59 & 7.59 \\
\hline Struvite Airprex ${ }^{\circledR}$ & 0.65 & 0.96 & 0.10 & 0.22 & 6.42 & 18.42 & 1.42 & 1.42 & 6.35 & 13.35 & 4.35 & 7.35 \\
\hline Biosolid ash untreated & 0.68 & 1.01 & 0.11 & 0.23 & 6.98 & 17.98 & 0.98 & 1.98 & 8.34 & 16.34 & 5.34 & 9.34 \\
\hline Biosolid ash Leachphos ${ }^{\circledR}$ & 0.65 & 0.98 & 0.09 & 0.22 & 6.60 & 17.60 & 0.60 & 1.60 & 7.54 & 14.54 & 5.54 & 8.54 \\
\hline Calcined ash AshDec ${ }^{\circledR}$ & 0.65 & 0.96 & 0.09 & 0.22 & 6.64 & 18.64 & 0.64 & 1.64 & 6.84 & 14.84 & 4.84 & 8.84 \\
\hline Mephrec converter slags & 0.64 & 0.96 & 0.09 & 0.22 & 6.78 & 18.78 & 0.78 & 1.78 & 6.84 & 13.84 & 4.84 & 7.84 \\
\hline Green waste compost OF & 0.79 & 1.23 & 0.12 & 0.22 & 7.73 & 19.73 & 0.73 & 1.73 & 8.54 & 16.54 & 5.54 & 9.54 \\
\hline Organic household waste compost OF & 0.74 & 1.12 & 0.07 & 0.27 & 7.23 & 19.23 & 1.23 & 1.23 & 7.94 & 15.94 & 5.94 & 9.94 \\
\hline Catering waste compost & 0.75 & 1.14 & 0.10 & 0.20 & 7.13 & 19.13 & 1.13 & 1.13 & 8.34 & 17.34 & 6.34 & 10.34 \\
\hline Cattle solid manure OF & 0.75 & 1.14 & 0.10 & 0.20 & 7.60 & 18.60 & 0.60 & 1.60 & 7.44 & 14.44 & 5.44 & 8.44 \\
\hline Phosphate rock OF & 0.77 & 1.19 & 0.06 & 0.26 & 6.71 & 17.71 & 0.71 & 1.71 & 6.64 & 12.64 & 4.64 & 7.64 \\
\hline Triple Superphosphate & 0.90 & 1.42 & 0.10 & 0.30 & 6.55 & 18.55 & 0.55 & 1.55 & 6.51 & 13.51 & 4.51 & 7.51 \\
\hline \multicolumn{13}{|l|}{ (b) } \\
\hline & $\begin{array}{l}\mathrm{Ni} \\
\mathrm{pH} 5 \\
\mathrm{~F} 0.1\end{array}$ & $\begin{array}{l}\mathrm{Ni} \\
\mathrm{pH} 5 \\
\mathrm{~F} 0.3\end{array}$ & $\begin{array}{l}\mathrm{Ni} \\
\mathrm{pH} 7 \\
\mathrm{~F} 0.1\end{array}$ & $\begin{array}{l}\mathrm{Ni} \\
\mathrm{pH} 7 \\
\mathrm{~F} 0.3\end{array}$ & $\begin{array}{l}\mathrm{Pb} \\
\mathrm{pH} 5 \\
\mathrm{~F} 0.1\end{array}$ & $\begin{array}{l}\mathrm{Pb} \\
\mathrm{pH} 5 \\
\mathrm{~F} 0.3\end{array}$ & $\begin{array}{l}\mathrm{Pb} \\
\mathrm{pH} 7 \\
\mathrm{~F} 0.1\end{array}$ & $\begin{array}{l}\mathrm{Pb} \\
\mathrm{pH} 7 \\
\mathrm{~F} 0.3\end{array}$ & $\begin{array}{l}\mathrm{Zn} \\
\mathrm{pH} 5 \\
\mathrm{~F} 0.1\end{array}$ & $\begin{array}{l}\mathrm{Zn} \\
\mathrm{pH} 5 \\
\mathrm{~F} 0.3\end{array}$ & $\begin{array}{l}\mathrm{Zn} \\
\mathrm{pH} 7 \\
\mathrm{~F} 0.1\end{array}$ & $\begin{array}{l}\mathrm{Zn} \\
\mathrm{pH} 7 \\
\mathrm{~F} 0.3\end{array}$ \\
\hline No fertilizer & 51.1 & 89.1 & 4.14 & 9.14 & 2.57 & 3.57 & 1.57 & 2.57 & 84.6 & 164 & 18.6 & 26.6 \\
\hline Organic household waste digestate OF & 52.2 & 91.2 & 4.20 & 9.20 & 2.04 & 4.04 & 2.04 & 2.04 & 97.0 & 192 & 21.0 & 30.0 \\
\hline Catering waste digestate & 51.1 & 89.1 & 4.08 & 9.08 & 1.95 & 3.95 & 1.95 & 1.95 & 88.1 & 172 & 19.1 & 27.1 \\
\hline Biosolid dewatered & 50.9 & 89.9 & 3.94 & 8.94 & 2.82 & 3.82 & 1.82 & 1.82 & 96.1 & 189 & 20.1 & 30.1 \\
\hline Meat and bone meal OF & 51.3 & 89.3 & 4.28 & 9.28 & 2.69 & 3.69 & 1.69 & 1.69 & 85.1 & 166 & 18.1 & 27.1 \\
\hline Struvite Stuttgart & 51.2 & 89.2 & 4.20 & 9.20 & 2.65 & 3.65 & 1.65 & 1.65 & 85.0 & 166 & 18.0 & 27.0 \\
\hline Struvite Airprex ${ }^{\circledR}$ & 51.5 & 88.5 & 4.52 & 8.52 & 2.01 & 4.01 & 2.01 & 2.01 & 84.7 & 165 & 18.7 & 26.7 \\
\hline Biosolid ash untreated & 51.3 & 89.3 & 4.30 & 9.30 & 2.55 & 4.55 & 1.55 & 2.55 & 99.1 & 197 & 21.1 & 31.1 \\
\hline Biosolid ash Leachphos ${ }^{\circledR}$ & 51.4 & 88.4 & 4.37 & 9.37 & 1.99 & 3.99 & 1.99 & 1.99 & 88.8 & 174 & 18.8 & 27.8 \\
\hline Calcined ash AshDec ${ }^{\circledR}$ & 51.7 & 89.7 & 3.74 & 8.74 & 2.18 & 4.18 & 2.18 & 2.18 & 94.2 & 185 & 20.2 & 29.2 \\
\hline Mephrec converter slags & 50.7 & 88.7 & 3.71 & 8.71 & 2.10 & 4.10 & 2.10 & 2.10 & 84.5 & 166 & 18.5 & 26.5 \\
\hline Green waste compost OF & 54.8 & 96.8 & 3.84 & 9.84 & 2.77 & 4.77 & 1.77 & 2.77 & 115 & 231 & 23.6 & 34.6 \\
\hline Organic household waste compost OF & 53.8 & 93.8 & 3.75 & 8.75 & 2.27 & 4.27 & 1.27 & 2.27 & 106 & 211 & 22.6 & 32.6 \\
\hline Catering waste compost & 53.7 & 94.7 & 3.74 & 9.74 & 2.77 & 4.77 & 1.77 & 2.77 & 111 & 221 & 23.6 & 34.6 \\
\hline Cattle solid manure OF & 52.8 & 92.8 & 3.79 & 8.79 & 2.72 & 3.72 & 1.72 & 1.72 & 91.7 & 181 & 19.7 & 28.7 \\
\hline Phosphate rock OF & 50.6 & 88.6 & 3.64 & 8.64 & 2.78 & 3.78 & 1.78 & 1.78 & 85.5 & 165 & 18.5 & 26.5 \\
\hline Triple Superphosphate & 51.4 & 88.4 & 4.37 & 9.37 & 2.73 & 3.73 & 1.73 & 1.73 & 85.5 & 166 & 18.5 & 26.5 \\
\hline
\end{tabular}


Table 8 Modelled soil accumulation of potentially toxic elements $\left(\mathrm{kg} \mathrm{ha}^{-1}\right)$ after 200 years of fertilizer application equivalent to $11 \mathrm{~kg}$ phosphorus per ha and year at four levels of $\mathrm{pH}$ and precipitation excess $\mathrm{F}$ values

\begin{tabular}{|c|c|c|c|c|c|c|c|c|c|c|c|c|}
\hline & $\begin{array}{l}\text { Cd } \\
\text { pH } 5 \\
\text { F } 0.1\end{array}$ & $\begin{array}{l}\mathrm{Cd} \\
\mathrm{pH} 5 \\
\mathrm{~F} 0.3\end{array}$ & $\begin{array}{l}\mathrm{Cd} \\
\mathrm{pH} 7 \\
\mathrm{~F} 0.1\end{array}$ & $\begin{array}{l}\mathrm{Cd} \\
\mathrm{pH} 7 \\
\text { F } 0.3\end{array}$ & $\begin{array}{l}\mathrm{Cr} \\
\mathrm{pH} 5 \\
\mathrm{~F} 0.1\end{array}$ & $\begin{array}{l}\mathrm{Cr} \\
\mathrm{pH} 5 \\
\mathrm{~F} 0.3\end{array}$ & $\begin{array}{l}\mathrm{Cr} \\
\mathrm{pH} 7 \\
\mathrm{~F} 0.1\end{array}$ & $\begin{array}{l}\mathrm{Cr} \\
\mathrm{pH} 7 \\
\mathrm{~F} 0.3\end{array}$ & $\begin{array}{l}\mathrm{Cu} \\
\mathrm{pH} 5 \\
\mathrm{~F} 0.1\end{array}$ & $\begin{array}{l}\mathrm{Cu} \\
\mathrm{pH} 5 \\
\mathrm{~F} 0.3\end{array}$ & $\begin{array}{l}\mathrm{Cu} \\
\mathrm{pH} 7 \\
\text { F } 0.1\end{array}$ & $\begin{array}{l}\mathrm{Cu} \\
\mathrm{pH} 7 \\
\mathrm{~F} 0.3\end{array}$ \\
\hline No fertilizer & 0.38 & 0.07 & 0.93 & 0.80 & 101 & 90 & 107 & 107 & 54 & 47 & 56 & 53 \\
\hline Organic household waste digestate $\mathrm{OF}$ & 0.46 & 0.11 & 1.1 & 0.92 & 107 & 96 & 113 & 113 & 69 & 61 & 71 & 67 \\
\hline Catering waste digestate & 0.40 & 0.08 & 0.96 & 0.83 & 102 & 91 & 108 & 107 & 57 & 51 & 59 & 56 \\
\hline Biosolid dewatered & 0.42 & 0.09 & 0.98 & 0.86 & 103 & 92 & 109 & 109 & 73 & 65 & 75 & 71 \\
\hline Meat and bone meal OF & 0.38 & 0.07 & 0.94 & 0.81 & 102 & 91 & 108 & 107 & 54 & 48 & 56 & 53 \\
\hline Struvite Stuttgart & 0.38 & 0.07 & 0.93 & 0.81 & 101 & 90 & 107 & 107 & 54 & 48 & 56 & 53 \\
\hline Struvite Airprex ${ }^{\circledR}$ & 0.38 & 0.07 & 0.93 & 0.81 & 102 & 90 & 107 & 107 & 55 & 48 & 57 & 54 \\
\hline Biosolid ash untreated & 0.43 & 0.10 & 1.0 & 0.88 & 104 & 93 & 110 & 109 & 79 & 71 & 82 & 78 \\
\hline Biosolid ash Leachphos ${ }^{\circledR}$ & 0.41 & 0.08 & 0.97 & 0.84 & 102 & 91 & 108 & 107 & 67 & 60 & 69 & 66 \\
\hline Calcined ash AshDec ${ }^{\circledR}$ & 0.38 & 0.07 & 0.94 & 0.81 & 105 & 93 & 111 & 110 & 66 & 58 & 68 & 64 \\
\hline Mephrec converter slags & 0.39 & 0.07 & 0.94 & 0.81 & 105 & 93 & 111 & 110 & 58 & 51 & 60 & 57 \\
\hline Green waste compost OF & 0.63 & 0.19 & 1.3 & 1.2 & 123 & 111 & 130 & 129 & 86 & 78 & 89 & 85 \\
\hline Organic household waste compost OF & 0.53 & 0.15 & 1.2 & 1.0 & 116 & 104 & 122 & 122 & 81 & 73 & 83 & 79 \\
\hline Catering waste compost & 0.55 & 0.16 & 1.2 & 1.1 & 118 & 106 & 124 & 124 & 85 & 76 & 87 & 83 \\
\hline Cattle solid manure OF & 0.55 & 0.16 & 1.2 & 1.1 & 110 & 99 & 117 & 116 & 64 & 57 & 66 & 63 \\
\hline Phosphate rock OF & 0.59 & 0.17 & 1.3 & 1.1 & 104 & 93 & 110 & 109 & 54 & 48 & 56 & 53 \\
\hline Triple superphosphate & 0.80 & 0.28 & 1.6 & 1.4 & 104 & 92 & 110 & 109 & 54 & 47 & 56 & 53 \\
\hline Soil background value ${ }^{\mathrm{a}}$ & 0.92 & 0.92 & 0.92 & 0.92 & 106 & 106 & 106 & 106 & 53 & 53 & 53 & 53 \\
\hline \multirow[t]{2}{*}{ Threshold $^{\mathrm{a}}$} & 3.25 & 3.25 & 3.25 & 3.25 & 244 & 244 & 244 & 244 & 163 & 163 & 163 & 163 \\
\hline & $\begin{array}{l}\mathrm{Ni} \\
\mathrm{pH} 5 \\
\mathrm{~F} 0.1\end{array}$ & $\begin{array}{l}\mathrm{Ni} \\
\mathrm{pH} 5 \\
\mathrm{~F} 0.3\end{array}$ & $\begin{array}{l}\mathrm{Ni} \\
\mathrm{pH} 7 \\
\mathrm{~F} 0.1\end{array}$ & $\begin{array}{l}\mathrm{Ni} \\
\mathrm{pH} 7 \\
\mathrm{~F} 0.3\end{array}$ & $\begin{array}{l}\mathrm{Pb} \\
\mathrm{pH} 5 \\
\mathrm{~F} 0.1\end{array}$ & $\begin{array}{l}\mathrm{Pb} \\
\mathrm{pH} 5 \\
\mathrm{~F} 0.3\end{array}$ & $\begin{array}{l}\mathrm{Pb} \\
\mathrm{pH} 7 \\
\mathrm{~F} 0.1\end{array}$ & $\begin{array}{l}\mathrm{Pb} \\
\mathrm{pH} 7 \\
\mathrm{~F} 0.3\end{array}$ & $\begin{array}{l}\mathrm{Zn} \\
\mathrm{pH} 5 \\
\text { F } 0.1\end{array}$ & $\begin{array}{l}\mathrm{Zn} \\
\mathrm{pH} 5 \\
\text { F } 0.3\end{array}$ & $\begin{array}{l}\mathrm{Zn} \\
\mathrm{pH} 7 \\
\text { F } 0.1\end{array}$ & $\begin{array}{l}\mathrm{Zn} \\
\mathrm{pH} 7 \\
\mathrm{~F} 0.3\end{array}$ \\
\hline No fertilizer & 51 & 13 & 98 & 93 & 78 & 77 & 79 & 78 & 159 & 80 & 225 & 217 \\
\hline Organic household waste digestate $\mathrm{OF}$ & 54 & 15 & 102 & 97 & 85 & 83 & 85 & 85 & 211 & 116 & 287 & 278 \\
\hline Catering waste digestate & 52 & 14 & 99 & 94 & 79 & 77 & 79 & 79 & 173 & 89 & 242 & 234 \\
\hline Biosolid dewatered & 53 & 14 & 100 & 95 & 80 & 79 & 81 & 81 & 205 & 112 & 281 & 271 \\
\hline Meat and bone meal OF & 51 & 13 & 98 & 93 & 78 & 77 & 79 & 79 & 163 & 82 & 230 & 221 \\
\hline Struvite Stuttgart & 51 & 13 & 98 & 93 & 78 & 77 & 79 & 79 & 162 & 81 & 229 & 220 \\
\hline Struvite Airprex ${ }^{\circledR}$ & 51 & 14 & 98 & 94 & 80 & 78 & 80 & 80 & 161 & 81 & 227 & 219 \\
\hline Biosolid ash untreated & 52 & 14 & 99 & 94 & 82 & 80 & 83 & 82 & 221 & 123 & 299 & 289 \\
\hline Biosolid ash Leachphos ${ }^{\circledR}$ & 51 & 14 & 98 & 93 & 79 & 77 & 79 & 79 & 178 & 93 & 248 & 239 \\
\hline Calcined ash AshDec ${ }^{\circledR}$ & 52 & 14 & 100 & 95 & 80 & 78 & 80 & 80 & 198 & 107 & 272 & 263 \\
\hline Mephrec converter slags & 52 & 14 & 99 & 94 & 79 & 77 & 79 & 79 & 162 & 81 & 228 & 220 \\
\hline Green waste compost OF & 61 & 19 & 112 & 106 & 110 & 108 & 111 & 110 & 282 & 166 & 373 & 362 \\
\hline Organic household waste compost OF & 57 & 17 & 107 & 102 & 98 & 96 & 99 & 98 & 244 & 139 & 327 & 317 \\
\hline Catering waste compost & 59 & 18 & 109 & 103 & 105 & 103 & 106 & 105 & 263 & 153 & 350 & 339 \\
\hline Cattle solid manure OF & 56 & 16 & 105 & 100 & 81 & 80 & 82 & 82 & 189 & 100 & 261 & 252 \\
\hline Phosphate rock OF & 52 & 14 & 99 & 94 & 78 & 77 & 79 & 79 & 162 & 82 & 229 & 221 \\
\hline Triple superphosphate & 51 & 14 & 98 & 93 & 78 & 77 & 79 & 79 & 162 & 82 & 229 & 221 \\
\hline Soil background value ${ }^{a}$ & 100 & 100 & 100 & 100 & 78 & 78 & 78 & 78 & 198 & 198 & 198 & 198 \\
\hline Threshold $^{\mathrm{a}}$ & 163 & 163 & 163 & 163 & 228 & 228 & 228 & 228 & 488 & 488 & 488 & 488 \\
\hline
\end{tabular}

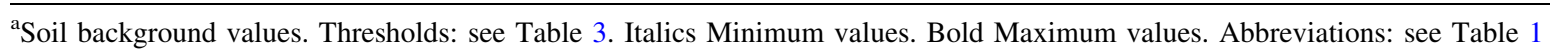


Fig. 1 Ratio between fertilizer input and atmospheric deposition of potentially toxic elements for the fertilizer application rate equivalent to $11 \mathrm{~kg} \mathrm{P} \mathrm{ha}^{-1}$ year $^{-1}$

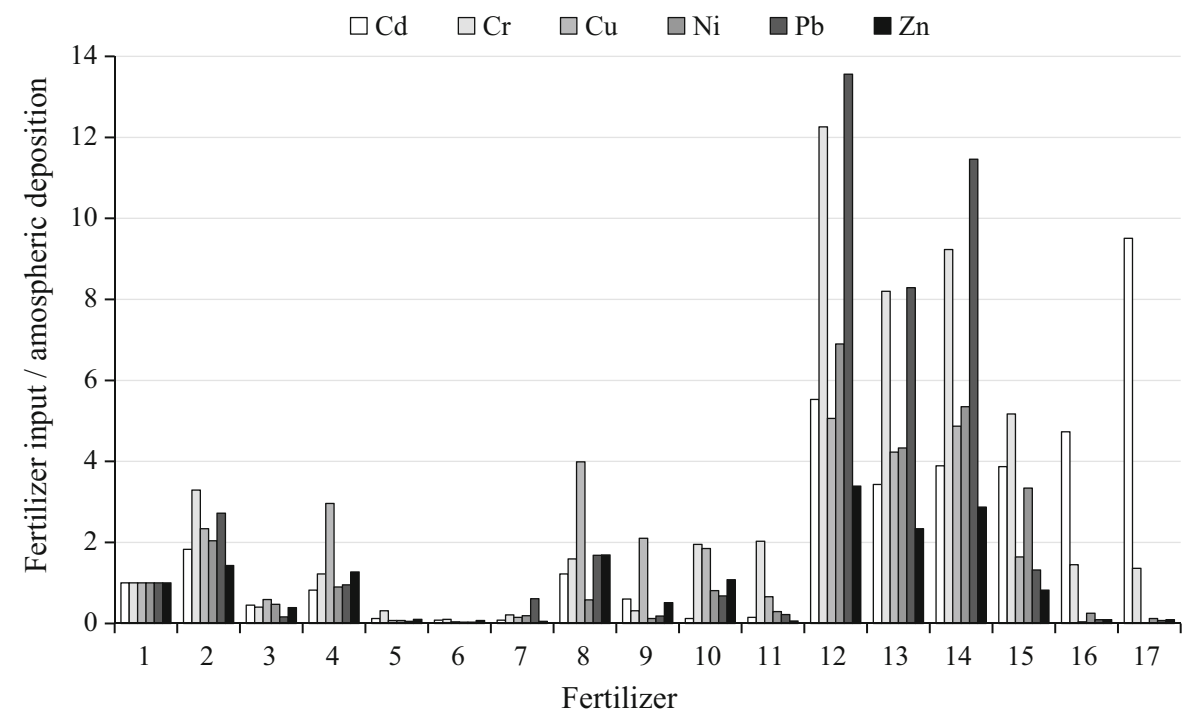

1 Atmospheric deposition

2 Organic household waste digestate $\mathrm{OF}$

3 Catering waste digestate

4 Biosolid dewatered

5 Meat and bone meal OF

6 Struvite Stuttgart

7 Struvite Airprex

8 Biosolid ash untreated

9 Biosolid ash Leachphos ${ }^{\circledR}$
10 Calcined ash ASH DEC (

11 Mephrec converter slag

12 Green waste compost OF

13 Organic household waste compost OF

14 Catering waste compost

15 Cattle solid manure OF

16 Phosphate rock OF

17 Triple superphosphate model for $\mathrm{PCB}, \mathrm{PAH}$ and $\mathrm{PCDD} / \mathrm{F}$ showed no accumulation potentials for these substances. A decrease of the POP amounts in soil was calculated during the assessed period, as indicated by lower values after 200 years than the initial soil background concentration, which means that imported and already accumulated POPs could degrade. For PCB, the amount of fertilizer input was very similar to the atmospheric deposition (Fig. 3). The contamination level (high or low) of PCB in fertilizers did not make any difference in accumulation.

For PAH, the contamination level mattered to some extent and resulted in higher PAH accumulation for composts compared to other fertilizers and atmospheric deposition. PCDD/F accumulation was negligible compared to the guidance value and the initial soil background concentration (Fig. 3).

Relevance of soil $\mathrm{pH}$ and precipitation excess for soil pollution

The partitioning coefficient KD varied strongly with $\mathrm{pH}$ value for all regarded PTEs. Among the PTEs, the ratio of $\mathrm{KD}$ at $\mathrm{pH} 7$ and $\mathrm{pH} 5$ was narrowest for $\mathrm{Cu}$, indicating the least $\mathrm{pH}$ dependence (Table 4).

Over all elements, the greatest accumulation was predicted in the scenario with $\mathrm{pH} 7$ and precipitation excess $\mathrm{F}=0.1 \mathrm{~m}$ year $^{-1}$, the lowest in the scenario with $\mathrm{pH} 5$ and precipitation excess $\mathrm{F}=0.3 \mathrm{~m}^{\text {year }}{ }^{-1}$. The model calculation indicated a major influence of $\mathrm{pH}$ value and the precipitation excess $\mathrm{F}$ on soil PTE accumulation risk, mainly on $\mathrm{Cd}, \mathrm{Ni}$ and $\mathrm{Zn}$ accumulation, whereas $\mathrm{Cr}, \mathrm{Cu}$ and $\mathrm{Pb}$ were less influenced (Fig. 2). This differentiation among the PTEs could not be clearly inferred from their KD values at varying $\mathrm{pH}$ value (Table 4). Comparing the scenarios, a high accumulation of PTEs was related to a low output by leaching and in harvested crop parts, and vice versa (Fig. 2; Table 7). However, for $\mathrm{Cr}, \mathrm{Cu}, \mathrm{Ni}, \mathrm{Pb}$ and $\mathrm{Zn}$ the influence of precipitation excess on the accumulation risk was negligible at $\mathrm{pH}$ 7. The PTE accumulation was clearly higher than the output for $\mathrm{Cr}, \mathrm{Cu}$, $\mathrm{Pb}$ and $\mathrm{Zn}$ at both $\mathrm{pH} 5$ and $\mathrm{pH}$ 7. For $\mathrm{Cd}$ and $\mathrm{Ni}$ this was the case only at $\mathrm{pH} 7$, while in soil with $\mathrm{pH} 5$ the reverse was observed (Tables 7,8 ). 
Fig. 2 Modelled soil accumulation of potentially toxic elements (y-axis) in \% of proposed threshold values after 200 years of fertilizer application equivalent to $11 \mathrm{~kg} \mathrm{P} \mathrm{ha}^{-1}$ year $^{-1}$ at four levels of $\mathrm{pH}$ and precipitation excess $\mathrm{F}$

$$
\text { ○ pH } 7 \text { F } 0.1 \quad \triangle \text { pH } 7 \text { F } 0.3
$$

$\diamond \mathrm{pH} 5$ F $0.1 \quad \times$ pH 5 F 0.3
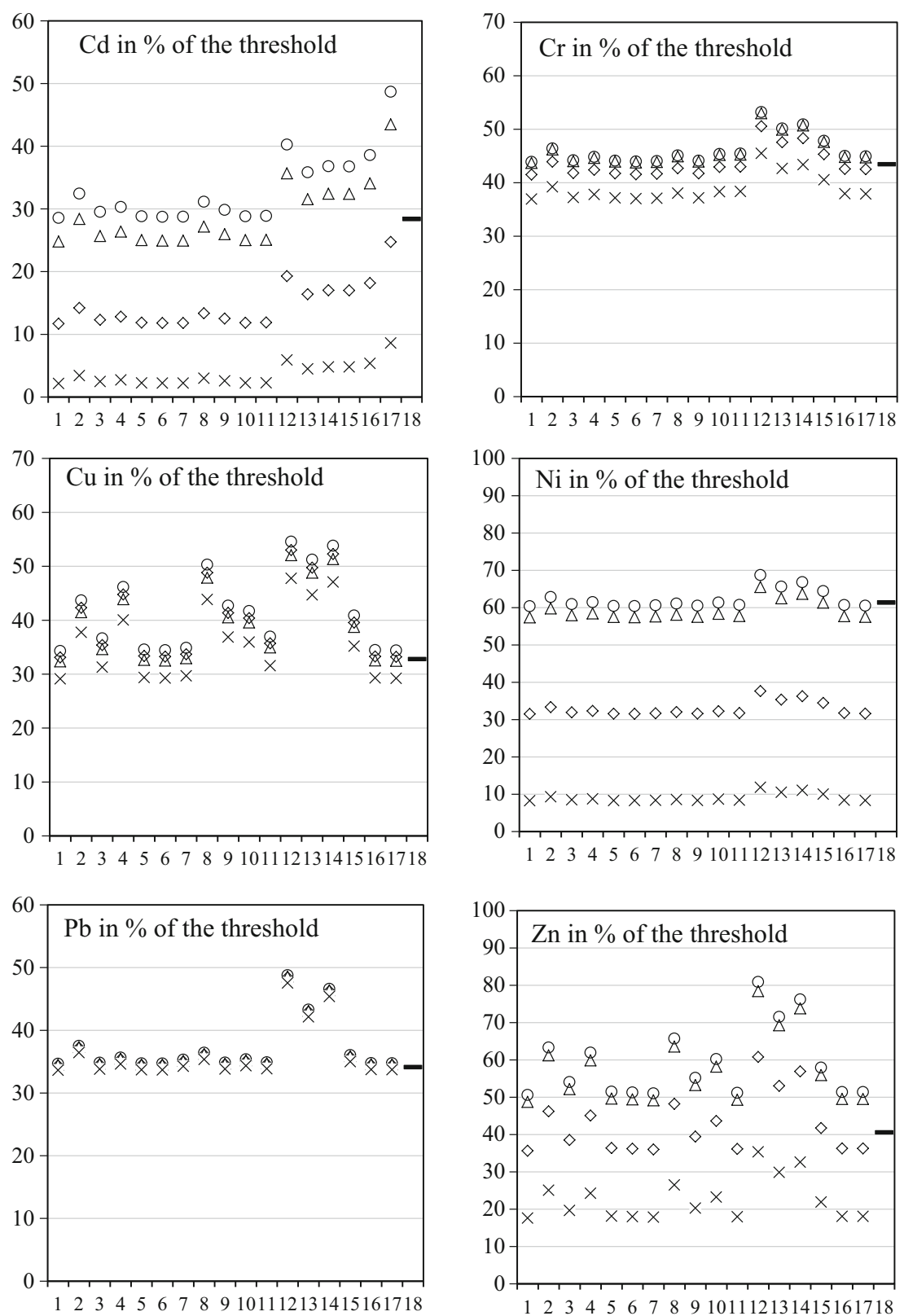

Legend for the $\mathrm{x}$-axis:

1 No fertilizer

2 Organic household waste digestate OF

3 Catering waste digestate

4 Biosolid dewatered

5 Meat and bone meal OF

6 Struvite Stuttgart

7 Struvite Airprex ${ }^{\circledR}$

8 Biosolid ash untreated

9 Biosolid ash Leachphos ${ }^{\circledR}$
10 Calcined ash ASH DEC (

11 Mephrec converter slags

12 Green waste compost OF

13 Organic household waste compost OF

14 Catering waste compost

15 Cattle solid manure OF

16 Phosphate rock OF

17 Triple Superphosphate

18 Initial soil background value 
Fig. 3 Modelled soil accumulation of PCB, PAH and PCDD/F (y-axis) in \% of soil guidance values after 200 years of fertilizer application equivalent to $11 \mathrm{~kg} \mathrm{P} \mathrm{ha}^{-1}$ year $^{-1}$ at two contamination levels
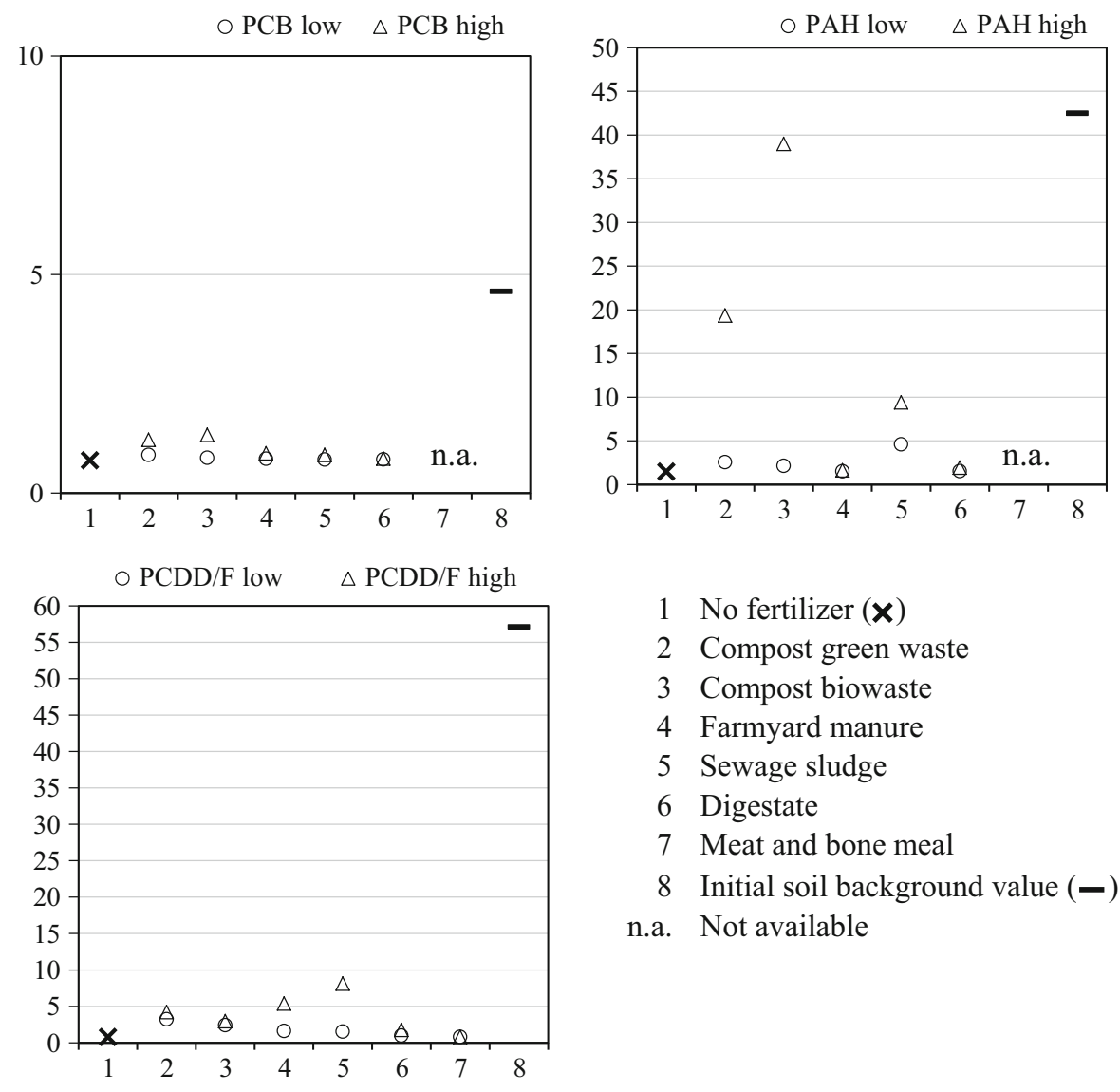

\author{
1 No fertilizer $(\mathbf{x})$ \\ 2 Compost green waste \\ 3 Compost biowaste \\ 4 Farmyard manure \\ 5 Sewage sludge \\ 6 Digestate \\ 7 Meat and bone meal \\ 8 Initial soil background value (-) \\ n.a. Not available
}

Relevance of PTE load of fertilizers for soil pollution

The soil accumulation risk of PTEs also varied depending on the PTE load applied with the fertilizers. More total PTE input led to a higher accumulation in soil but as well to a higher output via leaching and crop uptake. The estimated overall output of PTEs over 200 years was very similar among the fertilizers, but strong related to soil reaction and precipitation (Table 7). For all fertilizers, a soil $\mathrm{pH}$ of 7 in combination with a low precipitation excess ( $\mathrm{F}$ $1.0 \mathrm{~m} \mathrm{year}^{-1}$ ) led to the highest accumulation potential, and this resulted in the lowest PTE output (Fig. 2; Table 7).

Triple superphosphate, green waste compost and phosphate rock had the highest $\mathrm{Cd}$ accumulation risk and the highest $\mathrm{Cd}$ output (Tables 7, 8). Lowest $\mathrm{Cd}$ accumulation and output risk can be expected from the use of struvites, meat and bone meal and calcined ash $\left(A \operatorname{shDec}{ }^{\circledR}\right.$ ). For $\mathrm{Cr}$, the highest accumulation and output risk was predicted by the model with composts, and the least accumulation and output risk with struvites, meat and bone meal, catering waste digestate and biosolid ash Leachphos ${ }^{\circledR}$. The elements $\mathrm{Cu}, \mathrm{Ni}, \mathrm{Pb}$ and $\mathrm{Zn}$ likewise showed the highest accumulation risk with composts. The maximum accumulation can be expected for the use of green waste composts. Calculations showed that the lowest potential $\mathrm{Cu}$ accumulation and lowest output is achieved with the use of triple superphosphate, struvites and phosphate rock. Lowest $\mathrm{Zn}$ accumulation and output was found for struvites meat and bone meal, Mephrec converter slags phosphate rock and triple superphosphate (Fig. 2; Table 7). Lowest $\mathrm{Pb}$ and $\mathrm{Ni}$ accumulation and output was achieved with the fertilization of struvites, meat and bone meal, catering waste digestate and triple superphosphate.

Fertilizers with a high PTE-to-phosphorus ratio, like composts, showed the highest potential for PTE accumulation in soil. Except for $\mathrm{Cd}$, the use of mined $\mathrm{P}$ sources (phosphate rock, triple superphosphate) was 
related to very low PTE inputs and a negligible soil accumulation risk (Fig. 2; Table 7).

\section{Discussion}

Pollutant input into soil

Comparing the inputs of PTEs and POPs over 200 years gave a good overview over the routes to soil and over conventional and recycled phosphorus fertilizers (RPFs). The inputs for PTEs (Table 5) point out that the current concentration of pollutants in soil has the largest share of all PTE sources in the 200-years simulation and that atmospheric deposition in this period was partly higher than inputs via fertilizers. Also for POPs atmospheric deposition was an important route to soil, comparable to fertilizer input (Table 6). The calculated total PTE inputs over 200 years were below the proposed thresholds in all cases (Table 5). From the variation in KD values with soil $\mathrm{pH}$ (Table 4), a lower $\mathrm{pH}$ effect on $\mathrm{Cu}$ leaching can be assumed compared to the other PTEs. The total inputs of the POPs PCB and PCDD/F also were lower than the guidance values. Fertilization with organic waste compost, however, resulted in a PAH input surpassing the guidance values (Table 6). The longterm accumulation risk of PTEs and POPs in European agricultural soils cannot be estimated by looking at their inputs only; also their output and decomposition have to be considered.

Implications of pollutant concentrations in $\mathrm{P}$ fertilizers

The estimates of the mass balance model showed that with none of the RPFs and POPs included in the model calculations the soil threshold values would be reached, even in a 200-years perspective. Therefore, PTEs are no longer excluding nutrient recycling for the assessed sources. Furthermore, the PTE inputs with fertilizers applied at a constant $\mathrm{P}$ fertilisation level were not correlated with the PTE concentrations in the fertilizers (Tables 2, 5). The fertilizer application rate is governed by the $\mathrm{P}$ concentration in the fertilizer. Therefore, materials with low $\mathrm{P}$ concentrations, such as composts, can result in a higher PTE and POP inputs to soil than fertilizers with higher pollutant and high $\mathrm{P}$ concentrations. Consequently, the pollutant-to-nutrient ratio is the main driving factor for pollutant flows applied to the soil. This implies that hypothesis (i), stating that PTE and POP concentrations in fertilizers are the main factor for their accumulation in soil, can be rejected. Therefore, any regulation aiming at a quality control of fertilizers should not be defined according to pollutant concentrations on a dry matter base but should consider the relation between contaminants and nutrients and their input per area and time.

The results also indicate that RPFs like sewage sludge and products obtained from sewage like struvite or from thermal approaches like the production of calcined phosphates via $\mathrm{AshDec}^{\circledR}$, Mephrec converter slags or Leachphos ${ }^{\circledR}$ can reduce the PTE accumulation risk. The advantage of thermal approaches is the decomposition of organic pollutants, but carbon and nitrogen are lost as well.

Accumulation and safety risks related to specific fertilizer sources

Urban organic waste, substrates of waste water treatment and by-products of meat production are the source materials for phosphorus recycling. The quality of the resulting fertilizers varies to a large extent.

\section{Urban organic waste}

As an example, the similar raw material of organic household waste digestate OF and organic household waste compost is compared. The material used for biogas production had twice as much $\mathrm{P}$ and consequently a lower PTE input than the composted material, possibly, because in the composting process carbonaceous bulking material is necessary. For anaerobic digestion, organic substances with a high degradability and high nutrient concentrations are suitable. In Vienna, separated organic household waste from the inner part of the city contains more easily degradable, nutrient rich material and is processed by anaerobic digestion due to its water content, whereas material collected in the suburbs is composted based on its content of grass and hedge trimmings. 


\section{Substrate of urban wastewater treatment}

The model predicted an unexpected low PTE and POP accumulation risk for biosolids, lower than that of composts. In agreement, some more recent studies on PTEs (Herter et al. 2003; Dittrich and Klose 2008; Eriksen et al. 2009; Magid 2013) found that soil contamination via biosolid application was within the legal framework. Accordingly, also the risk to human health via dietary intake of POPs from crops grown on biosolid treated soils was found to be minimal (Eriksen et al. 2009; Haynes et al. 2009; Smith 2009b). If the pollutant-to-nutrient ratio allows the use of sewage sludge as fertilizer, it is also economically very efficient.

RPFs based on biosolid ash, like untreated ash, Leachphos ${ }^{\circledR}$ and Mephrec converter slag have the advantage that organic contaminants are destroyed during the incineration procedure. Products made of biosolid ash are still in a pilot-scale, so uncertainties in data quality are presumed. Still, the rate of P recovery from the raw sludge was high, ranging from 70 to $98 \%$ for Biosolid ash Leachphos ${ }^{\circledR}$, Mephrec calcined slags and Mg-treated ash via AshDec ${ }^{\circledR}$ (Herzel et al. 2015b). Cleaned ashes had a low PTE and no POP accumulation risk. The $\mathrm{AshDec}^{\circledR}$ depollution process for production of $\mathrm{Mg}$-ash can reduce $\mathrm{Cd}, \mathrm{Cu}, \mathrm{Hg}, \mathrm{Pb}, \mathrm{Mo}$, $\mathrm{Sn}$ and $\mathrm{Zn}$, but not $\mathrm{Cr}$ and $\mathrm{Ni}$ (Herzel et al. 2015a). The PTE removal is selective and depends on the process, it might differ in future full-scale plants (Kraus and Seis 2015).

Magnesium-ammonium-phosphate

(struvite) showed the lowest soil PTE accumulation risk among the inorganic fertilizers in this ranking due to a very high $\mathrm{P}$ content. Data on POPs were not available. Crystallisation of (struvite) takes place in sewage sludge before dewatering (Stuttgart process) or in processed water after primary clarification (Airprex ${ }^{\circledR}$ process) and is a stoichiometric process in which a very little amount of pollutants is co-precipitated in the final product. This low PTE amount in struvite was also found by Kraus and Seis (2015). Struvite production has a P recovery rate of $7 \%$ (Airprex ${ }^{\circledR}$ ) to $45 \%$ (Stuttgart Sludge Leaching), also depending on wastewater P content (Herzel et al. 2015b). Struvite would be very suitable for organic farming because of the favourable P-to-contaminant ratio combined with low water solubility and a high $\mathrm{P}$ fertilizer effectiveness (Möller et al. 2017).
Slaughterhouse waste

Meat and bone meal, which is allowed in organic farming, is the fertilizer source with the lowest soil PTE accumulation risk in this estimation because of very low contamination (food grade raw material) and a high $\mathrm{P}$ content. In terms of pathogens, meat and bone meal can be considered as much safer than animal manure and several other organic fertilizers (Möller 2015).

\section{Inorganic reference fertilizers}

Triple superphosphate had a higher accumulation estimate for $\mathrm{Cd}$ than green waste compost $\mathrm{OF}$, for phosphate rock it was a little lower than for green waste compost, all other PTEs were on a very low level. Nziguheba and Smolders (2008) found a significant correlation between $\mathrm{Cd}, \mathrm{Ni}$ and $\mathrm{P}$ content in phosphorus ore leading to elevated $\mathrm{Cd}$ and $\mathrm{Ni}$ concentration in P fertilizers. Mineral $\mathrm{P}$ fertilizers are a major source of PTEs in the food chain (Kratz and Schnug 2005).

Source material and production process of RPFs determined their pollutant and $\mathrm{P}$ concentration, and thereby the pollutant-to-P ratio of the fertilizers. In this way, source material and production process of RPFs, but not their pollutant concentration on a dry matter base, affect the input and soil accumulation risk of PTE and POP.

Hypothesis (ii), stating that the source material and the production process of RPFs determine their contamination and the risk of PTE and POP accumulation in soil, was therefore largely confirmed.

\section{Comparison of recycled phosphorus fertilizers to commonly used fertilizers}

The present estimation indicates a lower PTE input and a lower risk of PTE accumulation in soil by applying RPFs then for most commonly used fertilizers, even in the worst-case scenario with a high $\mathrm{pH}$ in soil and low precipitation excess. Therefore, the contamination of RPFs with PTEs is not the main constraint limiting recycling, as also indicated by other recent studies (e.g. Eriksen et al. 2009). Furthermore, this assessment estimated a lower $\mathrm{Cd}$ input to soil if commonly used fertilizers like green waste compost, triple superphosphate and phosphate 
rock were replaced by RPFs, except composts. Cd poses a health risk at concentrations below those causing phytotoxicity (McLaughlin et al. 1999). Therefore, Cd belongs to the most important elements to consider in terms of food-chain contamination (McLaughlin et al. 1999).

The model estimates contradict several older studies that have shown accumulation of PTEs in soils after long-term application of high amounts of biosolids (McGrath 1984; McGrath et al. 1995; Sekhar et al. 2002; Udom et al. 2004; Dai et al. 2006). In the last three decades there has been a significant reduction of PTEs and POPs in organic residues and the sewage systems due to implementation of environmental regulations in Europe. These include the source separated collection of organic household waste compared to mechanically sorted feedstock (Epstein et al. 1992; Sharma et al. 1997; Amlinger et al. 2004), as well as separation of wastewaters from industry and households and changing waste management technologies (Herter et al. 2003; Amlinger et al. 2004; Magid et al. 2006; Schroder et al. 2008; Eriksen et al. 2009). The quality of recycled $P$ fertilizers has improved, in the case of biosolids with a 3-5-fold decline in the content of PTEs ( $\mathrm{Cd}, \mathrm{Hg}, \mathrm{Pb}, \mathrm{Zn}$ ) since the late seventies (Herter et al. 2003; Amlinger et al. 2004; Kupper 2008; Eriksen et al. 2009; Milieu Ltd et al. 2010). The implementation of source segregated collection of urban organic household wastes has reduced the PTE concentration in compost typically by a factor of 2-10 compared to mechanically separated material (Amlinger et al. 2004). The release of POPs into the environment was reduced by the implementation of the Aarhus Protocol and the Stockholm Convention on Persistent Organic Pollutants and by technical improvements in industry like filters and high temperature combustion (Leschber 2006). These achievements should be considered.

Many fertilizers are not allowed in organic farming, like digestates containing non-certified row material (e.g. catering waste digestate), sewage sludge based fertilizers (struvite, ashes, sewage sludge), or not used because of private association rules, like meat and bone meal (Løes et al. 2017). The present calculation for PTE and POP accumulation in soil showed that the regular use of the $\mathrm{P}$ fertilizer mentioned above, implies a lower risk of contaminant input and accumulation than using composts, farmyard manure and phosphate rock, which are mostly used in organic farming. The
RPFs struvite, meat and bone meal, catering waste digestate, the ash products Mephrec, AshDec ${ }^{\circledR}$ and Leachphos ${ }^{\circledR}$ had a very low input and accumulation risk of contaminants compared to commonly used fertilizers. Consequently, hypothesis (iii), stating that the regular use of recycled phosphorus fertilizers causes higher soil pollution than established fertilizers, was disproved with respect to the PTE and POP accumulation risk.

The relevance of soil and climatic conditions

The balance model estimated a strong influence of soil reaction ( $\mathrm{pH}$ value) and precipitation excess on $\mathrm{Cd}, \mathrm{Ni}$ and $\mathrm{Zn}$ mobility in soil and a lesser effect on $\mathrm{Cr}, \mathrm{Cu}$ and $\mathrm{Pb}$. This diverging effect on $\mathrm{pH}$ and precipitation excess among the PTEs was not clearly related to the $\mathrm{pH}$ effect on their KD values (Table 4). $\mathrm{Cu}$ tends to bind to organic ligands and $\mathrm{Pb}$ is strongly absorbed by humic matter at $\mathrm{pH} 4$ and above (Oorts 2013; Steinnes 2013b). Under the assumed conditions, the risk of $\mathrm{Cd}$, $\mathrm{Ni}$ and $\mathrm{Zn}$ accumulation in the topsoil decreased considerably with decreasing soil $\mathrm{pH}$ and increasing precipitation excess (Fig. 2) due to increasing leaching losses (Table 7). Leaching was most relevant for $\mathrm{Cd}, \mathrm{Cr}, \mathrm{Ni}$ and $\mathrm{Zn}$ at $\mathrm{pH} 5$ and precipitation excess $\mathrm{F}=0.3 \mathrm{~m}$ year $^{-1}$, relocating the problem of environmental pollution to the water bodies. Therefore, hypothesis (iv), stating that the soil and climatic conditions have a minor relevance on the soil accumulation risk of PTEs, was disproved for PTEs.

Strengths and limitations of the model approach

The used mass balance models provide an adequate insight into the potential risk of PTE and POP accumulation in an average central and northern European agricultural top soil. In addition to the main PTE input routes, i.e. fertilizers, liming and atmospheric deposition, the PTE model regarded soil background concentrations and the main outputs by leaching and in harvested crop parts. Leaching is mainly affected by the precipitation excess and the partitioning coefficient KD of PTEs between solid phase and the solution phase. Among the factors influencing $\mathrm{KD}$, the $\mathrm{pH}$ value had the largest effect (Young 2013; Kabata-Pendias 2011). Therefore the model differentiated between two $\mathrm{pH}$ values in soil and two precipitation regimes and combined them to 
four scenarios. These scenarios gave estimates of PTE behaviour in European agricultural soils and PTE distribution among the environmental compartments soil, water and crop. In fact, soil is more complex and beside the considered determining factors, the soil type, soil organic matter, redox potential, temperature, $\mathrm{Fe} / \mathrm{Mn}$ oxides, Ca content, erosion and other variables play a role in PTE behaviour and distribution in soil (Young 2013). Therefore, specific sites can deviate from the simulations. Any comprehensive, site-specific assessment of the accumulation risk of contaminants needs to take the local atmospheric deposition and soil conditions into consideration. In addition, a regular monitoring of the total and soluble contents of potentially harmful substances should complement an improved P recycling approach.

The mass balance calculations were based on an average $\mathrm{P}$ withdrawal of $11 \mathrm{~kg} \mathrm{P} \mathrm{ha}^{-1}$ year $^{-1}$ on European stockless organic farms. The average $\mathrm{P}$ fertilizer consumption of arable land in Europe calculated by Smolders (2013) was $9.6 \mathrm{~kg} \mathrm{P} \mathrm{ha}^{-1}$ year $^{-1}$. So the estimates of this study can be extended beyond organic farming to the average European situation on arable land. For more intense systems, high fertilisation scenarios should be calculated.

Most POPs are apolar organic compounds adsorbed to the organic matter in the soil and therefore not directly affected by $\mathrm{pH}$ and precipitation excess and little prone to leaching (Jones and De Voogt 1999). Although precipitation excess can affect runoff generated erosion and POP transfer into surface waters, already by regarding their half-life time in relation to their input by fertilizer application, their estimated accumulation risk in soil was low to very low. Without the model it would have been impossible, e.g. to realistically estimate $\mathrm{PAH}$ accumulation and to predict if it would reach the guidance values in 200 years, because fertilization with organic waste compost would result in PAH input five times above the guidance limit.

\section{Environmental cycling of pollutants}

There is evidence that PTEs are no longer a major constraint limiting the use of RPFs in agriculture. The systematic use of recycled $P$ fertilizers in Switzerland before the ban of biosolids, for example, contributed to about $17 \%$ of the PTEs and $20 \%$ of the POPs in the food chain while atmospheric deposition, manure, mineral fertilizer and pesticides were other important input sources (Herter et al. 2003). For several POPs (e.g. PCBs), environmental cycling, mainly atmospheric deposition, is the main source to biosolids and other waste streams (Smith 2009b; Kupper 2008). Human daily exposure to chemicals (emerging pollutants) contained e.g. in packaging materials (Phthalate, Bisphenol A), cosmetics (UV-filter, fragrances), preservatives, flame retardants or drugs are a much higher risk than a potential contamination through the detour recycled fertilizer (Herter et al. 2003). Only reducing the chemical release into the environment, e.g. by excluding potential point sources from the sewage or other treatment systems, will tackle this problem at its source (Herter et al. 2003; Kupper 2008).

\section{Conclusions}

The calculated PTE inputs by P fertilizers for substituting phosphorus withdrawal via cash crops on organic farms, by liming and by atmospheric deposition over a 200-years period were small compared to the already existing PTE background concentrations in soil. Fertilizers with a high PTE-to-phosphorus ratio, like composts, showed the highest PTE input to soil. The lowest PTE input was found for meat and bone meal, struvite, digestate of catering waste and treated ashes.

The $\mathrm{Cd}, \mathrm{Cr}, \mathrm{Cu}, \mathrm{Ni}, \mathrm{Pb}$, and $\mathrm{Zn}$ accumulation in soil estimated by the mass balance model did not exceed proposed soil threshold values. Present results therefore indicate that the PTE content in most of the currently available recycled $\mathrm{P}$ sources does not exclude them from being used as $\mathrm{P}$ fertilizers. The PTE loads of recycled $\mathrm{P}$ fertilizers are no longer a major factor limiting the recycling of nutrients like $\mathrm{P}$ from our urban areas back to agriculture. Nevertheless, sustainable RPF application requires a regular PTE monitoring, as a high contamination risk for single batches still persists.

A high $\mathrm{P}$ concentration in fertilizers resulted in a considerably lower PTE flow per unit of P. Accordingly, composts had the highest accumulation estimates of PTEs among the fertilizers, except for $\mathrm{Cd}$. Struvite, meat and bone meal and digestate of catering waste were the recycled P fertilizers with the lowest potential of harmful effects in soil. Therefore the 
pollutant-to-nutrient ratio is better suited to determine the quality of recycled $\mathrm{P}$ fertilizers than the actual standards to measure and assess pollutants on a dry matter base.

The estimated accumulation risk of the addressed persistent organic pollutants was also minor. However, there is a need to continue examining the impact of new contaminants entering the food chain.

To reduce the contamination of waste streams it is necessary to reduce and replace harmful substances at their source.

Acknowledgements Open access funding provided by University of Natural Resources and Life Sciences Vienna (BOKU). The authors are grateful to Astrid Oberson and Jakob Magid for valuable advice during the assessments. This work was carried out within the EU-project IMPROVE-P. The authors gratefully acknowledge the financial support for this project provided by the CORE Organic II Funding Bodies, being partners of the FP7 ERA-Net project, CORE Organic II (www. coreorganic2.org).

Open Access This article is distributed under the terms of the Creative Commons Attribution 4.0 International License (http:// creativecommons.org/licenses/by/4.0/), which permits unrestricted use, distribution, and reproduction in any medium, provided you give appropriate credit to the original author(s) and the source, provide a link to the Creative Commons license, and indicate if changes were made.

\section{References}

Amlinger F, Pollak M, Favoino E (2004) Heavy metals and organic compounds from wastes used as organic fertilisers. Study on behalf of the European Commission, DirectorateGeneral Environment, ENV. A, 2

Arellano L, Fernández P, Fonts R, Rose NL, Nickus U, Thies H, Stuchlik E, Camarero L, Catalan J, Grimalt JO (2015) Increasing and decreasing trends of the atmospheric deposition of organochlorine compounds in European remote areas during the last decade. Atmos Chem Phys Discuss 15:3415-3453. https://doi.org/10.5194/acpd-153415-2015

AROMIS (2016) Heavy metals and nutrients in European cattle solid manure. Database AROMIS, assessment and reduction of heavy metal input into agro-ecosystems. http:// daten.ktbl.de/aromis/heavyMetal.do. Accessed 26 Feb 2017

Beckmann U, Grünbeck A, Hänsel M, Karalus W, Kolbe H, Schuster M, Arp B, Beese G, Krelling B, Pölitz B, Auerbach D (2001) Getreide im Ökologischen Landbau Informationen für Praxis und Beratung. Sächsische Landesanstalt für Landwirtschaft

Beníšek M, Kukučka P, Mariani G, Suurkuusk G, Gawlik BM, Locoro G, Giesy JP, Bláha L (2015) Dioxins and dioxin- like compounds in composts and digestates from European countries as determined by the in vitro bioassay and chemical analysis. Chemosphere 122:168-175. https://doi. org/10.1016/j.chemosphere.2014.11.039

Berry PM, Stockdale EA, Sylvester-Bradley R, Philipps L, Smith KA, Lord EI, Watson CA, Fortune S (2003) N, P and $\mathrm{K}$ budgets for crop rotations on nine organic farms in the UK. Soil Use Manag 19:112-118. https://doi.org/10.1111/ j.1475-2743.2003.tb00289.x

Berset JD, Holzer R (1995) Organic micropollutants in swiss agriculture: distribution of polynuclear aromatic hydrocarbons $(\mathrm{PAH})$ and polychlorinated biphenyls (PCB) in soil, liquid manure, sewage sludge and compost samples; a comparative study. Intern $\mathrm{J}$ Environ Anal Chem 59:145-165

Brändli RC, Bucheli TD, Kupper T, Furrer R, Stahel WA, Stadelmann FX, Tarradellas J (2007a) Organic pollutants in compost and digestate. Part 1. Polychlorinated biphenyls, polycyclic aromatic hydrocarbons and molecular markers. J Environ Monit 9:456-464. https://doi.org/10. 1039/B617101J

Brändli RC, Kupper T, Bucheli TD, Zennegg M, Huber S, Ortelli D, Müller J, Schaffner C, Iozza S, Schmid P, Berger U, Edder P, Oheme M, Stadelmann FX, Tarradellas J (2007b) Organic pollutants in compost and digestate. Part 2 . Polychlorinated dibenzo- $p$-dioxins, and -furans, dioxinlike polychlorinated biphenyls, brominated flame retardants, perfluorinated alkyl substances, pesticides, and other compounds. J Environ Monit 9:465-472. https://doi.org/ 10.1039/B617103F

Bruckmann P, Hiester E, Klees M, Zetzsch C (2013) Trends of $\mathrm{PCDD} / \mathrm{F}$ and $\mathrm{PCB}$ concentrations and depositions in ambient air in Northwestern Germany. Chemosphere 93:1471-1478. https://doi.org/10.1016/j.chemosphere. 2013.07.029

Clarke RM, Cummins E (2015) Evaluation of "classic" and emerging contaminants resulting from the application of biosolids to agricultural lands: a review. Hum Ecol Risk Assess Int J 21:492-513. https://doi.org/10.1080/ 10807039.2014.930295

Cooper J, Reed EY, Hörtenhuber S, Lindenthal T, Løes A-K, Mäder P, Magid J, Oberson A, Kolbe H, Möller K (2017) Phosphorus availability on organically managed farms in Europe. Nutr Cycl Agroecosyst. https://doi.org/10.1007/ s10705-017-9894-2

Cordell D, White S (2011) Peak phosphorus: clarifying the key issues of a vigorous debate about long-term phosphorus security, review. Sustainability 3:2027-2049. https://doi. org/10.3390/su3102027

Creaser CS, Wood MD, Alcock RE, Copplestone D (2007) UK Soils and Herbage Survey. Report 8: Environmental concentrations of polychlorinated biphenyls (PCBs) in UK soil and herbage. Environment Agency, Bristol. ISBN: 978-184432-773-7

CSTEE (2002) Opinion on Member State assessments of the risk to health and the environment from cadmium in fertilizers. http://ec.europa.eu/health/ph_risk/committees/sct/ documents/out162_en.pdf. Accessed 17 July 2017

Dai JY, Chen L, Zhao JF, Ma N (2006) Characteristics of sewage sludge and distribution of heavy metal in plants 
with amendment of sewage sludge. J Environ Sci 18:1094-1100

De Vries W, Groenenberg JE, Lofts S, Tipping E, Posch M (2013) Critical loads of heavy metals for soils. In: Alloway BJ (ed) Heavy metals in soils, 3rd edn. Springer, Amsterdam, pp 211-237

Desmidt E, Ghyselbrecht K, Zhang Y, Pinoy L, Van der Bruggen B, Verstraete W, Rabaey K, Meesschaert B (2014) Global phosphorus scarcity and full-scale p-recovery techniques: a review. Crit Rev Environ Sci Technol 45(4):336-384

Dittrich B, Klose R (2008) Schwermetalle in DüngemittelnBestimmung und Bewertung von Schwermetallen in Düngemitteln, Bodenhilfsstoffen und Kultursubstraten. Schriftenreihe der Sächsischen Landesanstalt für Landwirtschaft. Heft 3/2008. https://publikationen.sachsen.de/ bdb/artikel/14898/documents/17816. Accessed 20 March 2017

EC (2008) Commission Regulation No 889/2008 laying down detailed rules for the implementation of Council Regulation (EC) No 834/2007 on organic production and labelling of organic products with regard to organic production, labelling and control

Egle L, Rechberger H, Zessner M (2015) Overview and description of technologies for recovering phosphorus from municipal wastewater. Resour Conserv Recycl 105:325-346. https://doi.org/10.1016/j.resconrec.2015.09. 016

Egle L, Amann A, Rechberger H, Zessner M (2016) Phosphor: Eine kritische und zugleich unzureichend genutzte Ressource der Abwasser- und Abfallwirtschaft-Stand des Wissens und Ausblick für Österreich und Europa. Oesterr Wasser Abfallwirtsch 68:118-133. https://doi.org/10. 1007/s00506-016-0295-6

Eljarrat E, Marsh G, Labandeira A, Barcelo D (2008) Effect of sewage sludges contaminated with polybrominated diphenylethers on agricultural soils. Chemosphere 71:1079-1086

Elser JJ (2012) Phosphorus: a limiting nutrient for humanity? Curr Opin Biotechnol 23(6):833-838

EPA (1999) Understanding variation in partitioning coefficient, $\mathrm{Kd}$, values, Volume II. https://www.epa.gov/sites/ production/files/2015-05/documents/402-r-99-004b.pdf. Accessed 20 March 2017

Epstein E, Chaney RL, Henry C, Logan TJ (1992) Trace elements in municipal solid waste compost. Biomass Bioenergy 1992:227-238

Eriksen GS, Amundsen CE, Bernhof A, Eggen T, Grave K, Halling- Sørensen B, Källquist T, Sogn T, Sverdrup L (2009) Risk assessment of contaminants in sewage sludge applied on norwegian soils. Norwegian Scientific Committee for Food Safety, Oslo

EU (2016) Persistant organic pollutants-environment-European Commission. http://ec.europa.eu/environment/ chemicals/international_conventions/index_en.htm. Accessed 20 Nov 2016

EU Directive 86/278/EEC (1986) Council Directive 86/278/ EEC of 12 June 1986 on the protection of the environment, and in particular of the soil, when sewage sludge is used in agriculture
EU Regulation (EC) No 1069/2009 of the European parliament and of the council of 21 October 2009 laying down health rules as regards animal by-products and derived products not intended for human consumption and repealing Regulation (EC) No 1774/2002 (Animal by-products Regulation)

FAO (2004) Position paper on dioxins and dioxin-like PCBs. Joint FAO/WHO Food Standards Programme. Codex Committee on Food Additives and Contaminants. ftp://ftp. fao.org/codex/Meetings/CCFAC/ccfac36/fa36_32e.pdf. Accessed 20 March 2017

Gawlik BM, Bidoglio G (2006) Background values in European soils and sewage sludges, part 3. Conclusions, comment and recommendations. In: Gawlik BM, Bidoglio G (eds) Results of a JRC-coordinated study on background values, European Commission. Joint Research Centre. http:// admin.isprambiente.it/it/progetti/suolo-e-territorio-1/usodei-fanghi-di-depurazione-in-agricoltura-attivita-dicontrollo-e-vigilanza-del-territorio/files/FANGHI_JRC_3. pdf. Accessed 20 March 2017

Govasmark E, Stäb J, Holen B, Hoornstra D, Nesbakk T, Salkinoja-Salonen M (2011) Chemical and microbiological hazards associated with recycling of anaerobic digested residue intended for agricultural use. Waste Manag $31: 2577-2583$

Hassan SM, Garrison A (1996) Distribution of chromium species between soil and porewater. Chem Speciat Bioavailab 8(3-4):85-103

Haynes RJ, Murtaza G, Naidu R (2009) Inorganic and organic constituents and contaminants of biosolids: implications for land application. Adv Agron 104:165-267

Herter U, Kupper T, Külling D, Kaufmann U, Vonmoos A (2003) Risikoabschätzung zur landwirtschaftlichen Abfalldüngerverwertung. FAL, Zürich

Herzel H, Adam C, Eicher N, Hermann L, Mallon J, Schaaf M, Stemann J (2015a) Sustainable sewage sludge management fostering phosphorus recovery and energy efficiency (PREX) — comparative review of ash processes. http://p-rex. eu/uploads/media/P-REX_D4_1_Comparative_review_ of_ash_processes.pdf. Accessed 22 Feb 2017

Herzel H, Stemann J, Nättorp A, Adam C (2015b) P-recovery technologies and products; P-REX. http://p-rex.eu/ uploads/media/2_P-REX_Recovery_Technolgies_ Amsterdam_Herzel.pdf. Accessed 22 Feb 2017

Hough RL, Booth P, Avery LM, Rhind S, Crews C, Bacon J, Campbell CD, Tomkins D (2012) Risk assessment of the use of PAS100 green composts in sheep and cattle production in Scotland. Waste Manag 32:117-130. https://doi. org/10.1016/j.wasman.2011.08.008

IFOAM (2017) Principles of organic agriculture. http://www. ifoam.bio/en/organic-landmarks/principles-organicagriculture. Accessed 2 Jan 2017

Jones KC, de Voogt P (1999) Persistent organic pollutants (POPs): state of the science. Environ Pollut 100(1-3):209-221

Kabata-Pendias A (2011) Trace elements in soils and plants, 4th edn. CRC Press, Boca Raton

Klinglmair M, Lemming C, Jensen LS, Rechberger H, Astrup TF, Scheutz C (2015) Phosphorus in Denmark: national and regional anthropogenic flows. Resour Conserv Recycl 105:311-324 
Kolbe H (2015) Wie ist es um die Bodenfruchtbarkeit im Ökolandbau bestellt: Nährstoffversorgung und Humusstatus? Bodenfruchtbarkeit-Grundlage erfolgreicher Landwirtschaft (BAD Tagungsband 2015), pp 89-123

Koppelaar R, Weikard H (2013) Assessing phosphate rock depletion and phosphorus recycling options. Glob Environ Change 23:1454-1466

Kratz S, Schnug E (2005) Schwermetalle in P-Düngern. Landbauforsch Völkenrode Spec 286:37-45

Kraus F, Seis W (2015) Sustainable sewage sludge management fostering phosphorus recovery and energy efficiency ( $\mathrm{P}$ REX). Quantitative risk assessment of potential hazards for humans and the environment: quantification of potential hazards resulting from agricultural use of the manufactured fertilizers. http://p-rex.eu/uploads/media/P-REX_D9_1_ Risk_Assessment_Kraus_2015.pdf. Accessed 20 March 2017

Kraus F, Kabbe C, Seis W (2017) Risk Assessment and Fertilizer regulation-a valuation with respect to recycled phosphorus materials from wastewater (P-REX). http://p-rex.eu/ uploads/media/Kraus_Kabbe_Seis._Risk_Assessment_ and_Fertilizer_regulation_-_A_valuation_with_respect_to_ recycled_phosphorus_materials_from_wastewater.pdf. Accessed $21 \mathrm{Feb} 2017$

Kupper T (2008) Belastung und Quellen organischer Schadstoffe im Klärschlamm und ihre Bedeutung im Zusammenhang mit dem Ausstieg aus der landwirtschaftlichen Klärschlammverwertung in der Schweiz. Österr Wasserund Abfallwirtsch 60:45-54

Langeveld K (2014) The use of secondary phosphates at ICL Fertilizers Europe. Workshop Abwasser-Phosphor-Dünger. http://www.umweltbundesamt.de/sites/default/files/ medien/378/dokumente/abstracts_workshop_abwasserphosphor-duenger_28_29_jan_2014.pdf. Accessed 1 March 2017

Lavado RS, Rodríguez M, Alvarez R, Taboada MA, Zubillaga MS (2007) Transfer of potentially toxic elements from biosolid-treated soils to maize and wheat crops. Agric Ecosyst Environ 118:312-318. https://doi.org/10.1016/j. agee.2006.06.001

Lerda D (2011) Polycyclic aromatic hydrocarbons (PAHs) Factsheet 4th edition. Technical notes Joint Research Centre, European Commission. https://ec.europa.eu/jrc/ sites/jrcsh/files/Factsheet\%20PAH_0.pdf. Accessed 20 March 2017

Leschber R (2006) Background values in European soils and sewage sludges, part 1 . Evaluation of the relevance of organic micro-pollutants in sewage sludge. In: Gawlik BM, Bidoglio G (eds) Results of a JRC-coordinated study on background values. Joint Research Centre, European Commission. http://www.isprambiente.gov.it/it/progetti/ suolo-e-territorio-1/uso-dei-fanghi-di-depurazione-inagricoltura-attivita-di-controllo-e-vigilanza-del-territorio/ files/FANGHI_JRC_1.pdf. Accessed 20 March 2017

LfU (Bayerisches Landesamt für Umwelt) (2007) Biogashandbuch Bayern, Materialienband. Augsburg. http://www.lfu. bayern.de/abfall/biogashandbuch

Lindenblatt C, Wendland M, Reitberger F, Müller C, Lebhn M, Bachmair H, Gehling R (2007) Biogashandbuch BayernMaterialienband, Kapitel 1.6. Bayerische Landesanstalt für
Landwirtschaft, Institut für Landtechnik und Tierhaltung (BayLfU)

Lindenthal T (2000) Phosphorvorräte in Böden, betriebliche Phosphorbilanzen, und Phosphorversorgung im Biologischen Landbau. Dissertation, Universität für Bodenkultur, Wien

Løes AK, Ogaard AF (1997) Changes in the nutrient content of agricultural soil on conversion to organic farming in relation to farm-level nutrient balances and soil contents of clay and organic matter. Acta Agric Scand Sect B 47:201-214

Løes AK, Bünemann EK, Cooper J, Hörtenhuber S, Magid J, Oberson A, Möller K (2017) Nutrient supply to organic agriculture as governed by EU regulations and standards in six European countries. Org Agric 7(4):395-418. https:// doi.org/10.1007/s13165-016-0165-3

Magid J (2013) A note on sewage sludge—risk assessments and fertilization value. Improve-P working paper Nr. 1, Plant and Environmental Sciences, Copenhagen University. http://www.orgprints.org/22629/1/22629.pdf. Accessed 20 March 2017

Magid J, Eilersen AM, Wrisberg S, Henze M (2006) Possibilities and barriers for recirculation of nutrients and organic matter from urban to rural areas: a technical theoretical framework applied to the medium-sized town Hillerod, Denmark. Ecol Eng 28:44-54

Mairitsch K, Wimmer W, Aigner S, Drosg B, Zweiler R, Tippel W (2011) Über die Erschließung des Potenzials biogener Haushaltsabfälle und Grünschnitt zum Zwecke der Verwertung in einer Biogasanlage zur optimierten energetischen und stofflichen Verwertung. Bundesministerium für Landund Forstwirtschaft, Umwelt und Wasserwirtschaft, Österreich

McGrath SP (1984) Metal concentrations in sludges and soil from a long-term field trial. J Agric Sci 103:25-35

McGrath SP, Chaudri AM, Giller KE (1995) Long-term effects of metals in sewage-sludge on soils, microorganisms and plants. J Ind Microbiol 14:94-104

McLaughlin MJ, Parker DR, Clarke JM (1999) Metals and micronutrients-food safety issues. Field Crop Res 60:143-163

Milieu Ltd, WRc, RPA (2010) for the European Commission. Environmental, economic and social impacts of the use of sewage sludge on land. Final report part I. http://ec.europa. eu/environment/archives/waste/sludge/pdf/part_i_report. pdf. Accessed 20 March 2017

Möller K (2015) Assessment of alternative phosphorus fertilizers for organic farming: meat and bone meal. Improve-P Fact Sheet 1-8. http://www.orgprints.org/29505/1/ moeller2015-factsheet-Meat-and-bone-meal.pdf. Accessed 20 March 2017

Möller K, Schultheiß U (2014) Organische Handelsdüngemittel im ökologischen Landbau-Charakterisierung und Empfehlungen für die Praxis. Kuratorium für Technik und Bauwesen in der Landwirtschaft e.V. (KTBL), Darmstadt

Möller K, Stinner W (2010) Effects of organic wastes digestion for biogas production on mineral nutrient availability of biogas effluents. Nutr Cycl Agroecosyst 87:395-413. https://doi.org/10.1007/s10705-010-9346-8

Möller K, Oberson A, Bünemann EK, Cooper J, Friedel JK, Glæsner N, Hörtenhuber S, Løes AK, Mäder P, Meyer G, 
Müller T, Symanczik S, Weissengruber L, Wollmann I, Magid J (2017) Improved phosphorus recycling in organic farming: navigating between constraints. Adv Agron. https://doi.org/10.1016/bs.agron.2017.10.004

Nesme T, Toublant M, Mollier A, Morel C, Pellerin S (2012) Assessing phosphorus management among organic farming systems: a farm input, output and budget analysis in southwestern France. Nutr Cycl Agroecosyst 92(2):225-236

Nogueira TAR, Melo WJ, Fonseca IM, Melo GMP, Marcussi SA, Marques MO (2009) Nickel in soil and maize plants grown on an oxisol treated over long time with sewage sludge. Chem Speciat Bioavailab 21:165-173

Nziguheba G, Smolders E (2008) Inputs of trace elements in agricultural soils via phosphate fertilizers in European countries. Sci Total Environ 390:53-57. https://doi.org/10. 1016/j.scitotenv.2007.09.031

Oberson A, Frossard E, Bühlmann C, Mayer J, Mäder P, Lüscher A (2013) Nitrogen fixation and transfer in grass-clover leys under organic and conventional cropping systems. Plant Soil 371:237-255

OECD (2005) Guideline for testing of chemicals, Annex 1, part 1: principles and strategies related to the testing of degradation of organic chemicals. http://www.oecd.org/ chemicalsafety/testing/34898616.pdf. Accessed 20 March 2017

Ohm M, Paulsen HM, Moos JH, Eichler-Löbermann B (2017) Long-term negative phosphorus budgets in organic crop rotations deplete plant-available phosphorus from soil. Agron Sustain Dev 37(17):1-9

ÖNORM S 2088-2 (2004) ÖNORM S2088-2, Altlasten-Teil 2 Gefährdungsabschätzung für das Schutzgut Boden

Oorts K (2013) Copper. In: Alloway BJ (ed) Heavy metals in soils, 3rd edn. Springer, Dordrecht, pp 367-394

Ott C, Rechtberger H (2012) The European phosphorus balance. Resour Conserv Recycl 60:159-172

Pinnekamp J, Everding W, Gethke K, Montag D, Weinfurtner K, Sartorius C, Von Horn J, Trettenborn F, Gäth S, Waida C, Fehrenbach H, Reinhardt J (2011) PhosphorrecyclingÖkologische und wirtschaftliche Bewertung verschiedener Verfahren und Entwicklung eines strategischen Verwertungskonzepts für Deutschland. ISA, ISI, IME

Puschenreiter M, Horak O (2000) Influence of different soil parameters on the transfer factor soil to plant of $\mathrm{Cd}, \mathrm{Cu}$, and $\mathrm{Zn}$ for what and rye. Die Bodenkultur 51(1):3-10

Rey-Salgueiro L, García-Falcón MS, Martínez-Carballo E, González-Barreiro C, Simal-Gándara J (2008) The use of manures for detection and quantification of polycyclic aromatic hydrocarbons and 3-hydroxybenzo[a]pyrene in animal husbandry. Sci Total Environ 406:279-286. https:// doi.org/10.1016/j.scitotenv.2008.07.059

Römer W, Lehne P (2004) Vernachlässigte Phosphor- und Kaliumdüngung im ökologischen Landbau senkt die biologische Stickstofffixierung bei Rotklee und den Kornertrag bei nachfolgendem Hafer. J Plant Nutr Soil Sci 167:106-113

Salminen R, Batista MJ, Bidovec M, Demetriades A, De Vivo B, De Vos W, Duris M, Gilucis A, Gregorauskiene V, Halamic J, Halamic J et al (2005) FOREGS Geochemical Atlas of Europe. Part 1: background information, methodology and maps, Europe. Geological Survey of Finland, Espoo
Sauvé S, Hendershot W, Allen HE (2000) Solid-solution partitioning of metals in contaminated soils: dependence on $\mathrm{pH}$, total metal burden, and organic matter. Environ Sci Technol 34:1125-1131. https://doi.org/10.1021/ es9907764

Scheidig K (2009) Metallurgisches phosphor-recycling: Präsentation und Diskussion des Mephrec-Verfahrens, 9. Gutachtersitzung zur BMBF/BMU-Förderinitiative P-Recycling 30.09.2009, Berlin

Scheidig K, Mallon J, Schaaf M (2014) Metallurgisches Phosphor-Recycling mit dem Mephrec-Verfahren. AbwasserPhosphor-Dünger Workshop 28/29 Januar 2014, Bundesanstalt für Materialforschung und -prüfung (BAM)

Schroder JL, Zhang H, Zhou D, Basta N, Raun WR, Payton ME, Zazulak A (2008) The effect of long-term annual application of biosolids on soil properties, phosphorus and metals. Soil Sci Soc Am J 72:73-82

Sekhar KC, Supriya KR, Kamala CT, Chary NS, Rao TN, Anjaneyulu Y (2002) Speciation, accumulation of heavy metals in vegetation grown on sludge amended soils and their transfer to human food chain-a case study. Toxicol Environ Chem 1:33-43

Sharma VK, Canditelli M, Fortuna F, Cornacchia G (1997) Processing of urban and agro-industrial residues by aerobic composting: review. Energy Convers Manag 38:453-478

Six L, Smolders E (2014) Future trends in soil cadmium concentration under current cadmium fluxes to European agricultural soils. Sci Total Environ 485-486:319-328. https://doi.org/10.1016/j.scitotenv.2014.03.109

Smith SR (2009a) A critical review of the bioavailability and impacts of heavy metals in municipal solid waste composts compared to sewage sludge. Environ Int 35:142-156

Smith SR (2009b) Organic contaminants in sewage sludge (biosolids) and their significance for agricultural recycling. Philos Trans R Soc A Math Phys Eng Sci 367:4005-4041. https://doi.org/10.1098/rsta.2009.0154

Smolders E (2013) Revisiting and updating the effect of phosphorus fertilisers on cadmium accumulation in European agricultural soils. Internat Fertiliser Society. Leek, Windsor, UK on 23rd May

Stein-Bachinger D, Bachinger D, Schmitt D (2004) Nährstoffmanagement im Ökologischen Landbau-Ein Handbuch für Beratung und Praxis. KTBL-Schrift 423, Darmstadt

Steinmetz H, Meyer C, Reinhardt T (2014) Interkommunales Pilotprojekt zur Phosphorrückgewinnung aus Klärschlammaschen in Baden-Württemberg. Institut für Siedlungswasserbau, Wassergüte- und Abfallwirtschaft der Universität, Stuttgart

Steinnes E (2013a) Mercury. In: Alloway BJ (ed) Heavy metals in soils, 3rd edn. Springer, Dordrecht, pp 411-428

Steinnes E (2013b) Lead. In: Alloway BJ (ed) Heavy metals in soils, 3rd edn. Springer, Dordrecht, pp 395-409

Stevens JL, Jones KC (2003) Quantification of PCDD/F concentrations in animal manure and comparison of the effects of the application of cattle manure and sewage sludge to agricultural land on human exposure to PCDD/Fs. Chemosphere 50:1183-1191

Suominen K, Verta M, Marttinen S (2014) Hazardous organic compounds in biogas plant end products-soil burden and risk to food safety. Sci Total Environ 491-492:192-199. https://doi.org/10.1016/j.scitotenv.2014.02.036 
Tavazzi S, Locoro G, Comero S, Sobiecka E, Loos R, Gans O, Ghiani M, Umlauf G, Suurkuusk G, Paracchini B et al (2012) Occurrence and levels of selected compounds in European Sewage Sludge Samples. Publications Office of the European Union

Udom BE, Mbagwu JSC, Adesodun JK, Agbim NN (2004) Distributions of zinc, copper, cadmium and lead in a tropical ultisol after long-term disposal of sewage sludge. Environ Int 30:467-470

Umlauf G, Christoph EH, Lanzini L, Savolainen R, Skejo H, Bidoglio G, Clemens J, Goldbach H, Scherer H (2010) $\mathrm{PCDD} / \mathrm{F}$ and dioxin-like PCB profiles in soils amended with sewage sludge, compost, farmyard manure, and mineral fertilizer since 1962. Environ Sci Pollut Res 18:461-470. https://doi.org/10.1007/s11356-010-0389-9
Watson CA, Atkinson D, Gosling P, Jackson LR, Rayns FW (2002) Managing soil fertility in organic farming systems. Soil Use Manag 18:239-247

Wollmann I, Möller K (2015) Assessment of alternative phosphorus fertilizers for organic farming: sewage precipitation products. Improve-P Fact sheet 1-12. http://orgprints.org/ 28142/. Accessed 22 Feb 2017

Wu L, Cheng M, Li Z, Ren J, Shen L, Wang S, Christie P et al (2012) Major nutrients, heavy metals and PBDEs in soils after long-term sewage sludge application. J Soils Sedim 12:531-541

Young SD (2013) Chemistry of heavy metals and metalloids. In: Alloway BJ (ed) Heavy metals in soils, 3rd edn. Springer, Dordrecht, pp 51-95

Zoboli O, Zessner M, Rechberger H (2016) Supporting phosphorus management in Austria: potential, priorities and limitations. Sci Total Environ 565:313-323 